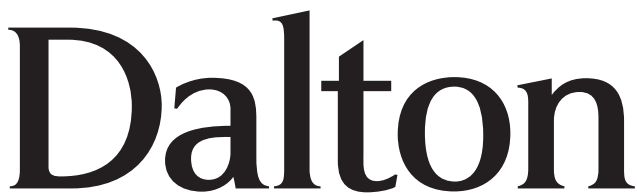

Transactions

An international journal of inorganic chemistry
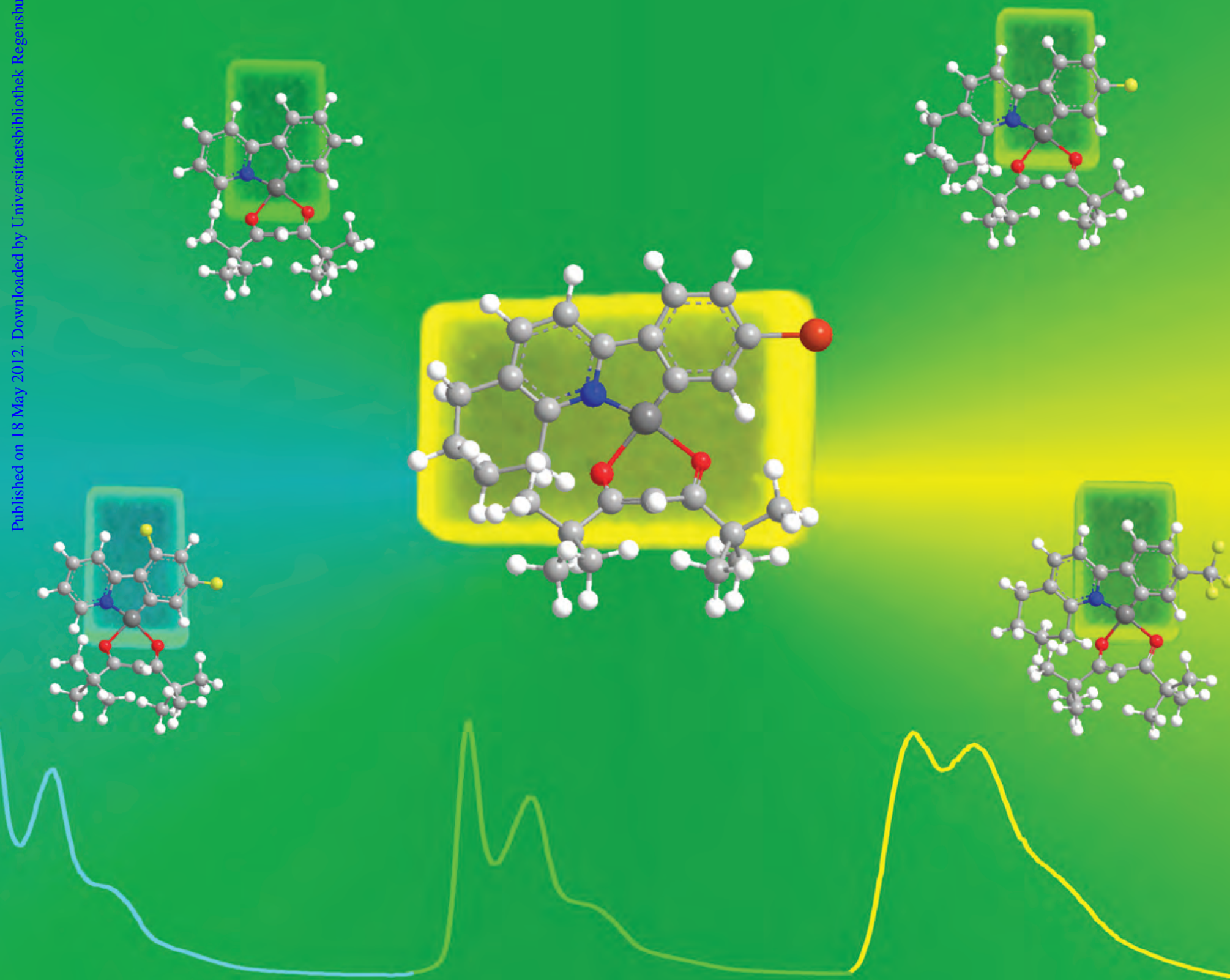


\title{
Transactions
}

Cite this: Dalton Trans., 2012, 41, 9623

wWw.rsc.org/dalton

PAPER

\section{Oxygen and temperature sensitivity of blue to green to yellow light-emitting Pt(II) complexes}

\author{
Cüneyt Karakus, ${ }^{a}$ Lorenz H. Fischer, ${ }^{b}$ Sebastian Schmeding, ${ }^{c}$ Johanna Hummel, ${ }^{c}$ Nikolaus Risch, ${ }^{c}$ \\ Michael Schäferling*b and Elisabeth Holder*a
}

\author{
Received 17th April 2012, Accepted 18th May 2012 \\ DOI: $10.1039 / \mathrm{c} 2 \mathrm{dt30835e}$
}

The synthesis and photophysical properties of a series of yellow-green to blue-green emitting heteroleptic, cyclometalated $\mathrm{Pt}(\mathrm{II})(\mathrm{acac})$ complexes based on substituted phenylpyridine and tetrahydroquinoline ligands is reported. The luminescence intensities and lifetimes of these compounds were also studied in poly(styrene) films with respect to their responses to oxygen and temperature. Particularly, due to the insensitivity to oxygen quenching, these complexes are promising candidates as inert reference dyes in optical sensors. On the other hand, the Pt(II) complex with 2-(4-bromophenyl)-5,6,7,8-

tetrahydroquinoline as $\mathrm{C}^{\wedge} \mathrm{N}$ ligand, displays a strong temperature quenching effect. The distinct response to temperature was additionally calibrated after incorporation in poly(vinylidene chloride-co-acrylonitrile) serving as oxygen-blocking matrix copolymer. The resulting yellow-green-emitting temperature sensor signifies an interesting alternative to the available mostly red emitting temperature-sensitive probes.

\section{Introduction}

Phosphorescent metal complexes are known to be of great practical interest in many fields of science and technology. They are successfully implemented in light-emitting diodes ${ }^{1}$ and photovoltaics, ${ }^{2}$ as well as of interesting use as labels, ${ }^{3}$ amongst many other relevant applications. Generally, triplet emitting transition metal complexes are the probes of choice applied in optical oxygen sensors. Oxygen indicators such as polypyridyl ruthenium(II) ${ }^{4}$ and iridium(III) complexes ${ }^{5-7}$ have successfully been used as an alternative to the widely used platinum(II)- or palladium(II)-porphyrins. ${ }^{8,9}$ However, some of these oxygen-sensitive probes have rather long luminescence decays up to milliseconds. In contrast, the lifetimes of heteroleptic Pt(II) or Ir(III) complexes are in the range from 1 to $10 \mu \mathrm{s}$ and are perfectly suited for timeresolved fluorescence detection and imaging, and in addition, they exhibit much higher quantum yields, photostabilities and sensitivities than related $\mathrm{Ru}(\mathrm{II})$ polypyridyl complexes. ${ }^{1,10-12}$ Contrary to the latter, $\operatorname{Pt}($ II) or Ir(III) complexes offer a tremendous ability for color tuning due to overlapping metal-ligand charge transfer (MLCT) transitions. ${ }^{1,11,12}$ Therefore, Pt(II) and Ir(III) complexes surpass the established luminescent oxygen-

\footnotetext{
${ }^{a}$ Functional Polymers Group and Institute of Polymer Technology,

University of Wuppertal, Gaußstr. 20, D-42097 Wuppertal, Germany.

E-mail: holder@uni-wuppertal.de; Fax:+49-202-439-3880;

Tel: +49-202-439-3879

${ }^{b}$ Institute of Analytical Chemistry, Chemo- and Biosensors, University of Regensburg, D-93040 Regensburg, Germany.

E-mail:michael.schaeferling@chemie.uni-regensburg.de

${ }^{c}$ Organic Chemistry, University of Paderborn, Warburger Str. 100,

D-33098 Paderborn, Germany
}

sensitive probes with respect to color tunability, brightness, sensitivity, dynamic range, and photostability. ${ }^{111,12}$

As a consequence of their favourable properties, it has already been demonstrated that platinum(II) complexes can be beneficially applied to chemosensors, ${ }^{13}$ light-emitting devices, ${ }^{14}$ photovoltaics ${ }^{15,16}$ and colorimetric oxygen sensors, ${ }^{17}$ and, due to their good cell membrane permeability, also in imaging of living cells. ${ }^{18}$ Moreover, $\mathrm{Pt}(\mathrm{II})$ complexes are also promising indicators for optical dual oxygen and temperature sensors, if they can be combined with a second indicator and the resulting pressure and temperature signals can be separated by optical filters. This can be achieved, if the indicators emit at sufficiently different wavelengths without spectral overlap. ${ }^{5,19,20}$

In the red spectral region, it was found that e.g. bis(coumarin acetylide)platinum(II) complexes demonstrate better oxygen sensitivity than tris(2,2'-bipyridyl)ruthenium(II) complexes. ${ }^{21}$ On the other hand, heteroleptic iridium(III) complexes, ${ }^{5,6}$ reveal excellent temperature sensitivity in the green spectral region compared to red-emissive platinum(II)-porphyrins that reveal only negligible temperature response. ${ }^{22,23}$

Generally, heteroleptic Pt(II) complexes with one cyclometalating and one ancillary ligand like (Z)-5-hydroxy-2,2,6,6-tetramethylhept-4-en-3-one are known to be rather stable, colortunable, well-soluble and emissive in the microsecond region, ${ }^{12}$ while their emissive states are assigned to mixed ${ }^{3}$ LC-MLCT states. $^{12}$

We describe the synthesis of yellow-green via green to bluegreen emitting heteroleptic cyclometalated platinum(II) complexes, which are based on substituted phenylpyridine- and tetrahydroquinoline-type $\mathrm{C}^{\wedge} \mathrm{N}$ ligands and (Z)-5-hydroxy-2,2,6,6tetramethylhept-4-en-3-one as ancillary ligand. Contrary to the commercial phenylpyridine-type $\mathrm{C}^{\wedge} \mathrm{N}$ ligands, the halogen- 
substituted tetrahydroquinoline $\mathrm{C}^{\wedge} \mathrm{N}$ ligands were available via a Mannich reaction. The resulting heteroleptic yellow-green to blue-green emitting platinum(II) compounds were mixed into poly(styrene) (PS) as polymer matrix to form sensitive films. Their temperature dependency was investigated by following their reduced luminescence lifetimes.

\section{Results and discussion}

\section{Synthesis and characterization}

A series of $\mathrm{C}^{\wedge} \mathrm{N}$ ligands $\mathbf{L 1 - L 5}$ (Chart 1) was used in order to subsequently prepare a set of $\mathrm{Pt}$ (II) complexes $\mathbf{1 - 5}$ revealing temperature sensitivity at short wavelengths. Rather than using C-C coupling chemistry, ${ }^{1,6,24}$ the synthesis of three tetrahydroquinoline-based $\mathrm{C}^{\wedge} \mathrm{N}$ ligands $\mathbf{L 3}-\mathbf{L 5}$ took place by the reaction of the respective Mannich bases ${ }^{25}$ with 1-morpholinocyclohexene, ${ }^{26}$ then forming 1,5-diketones, ${ }^{25}$ which were cyclized with

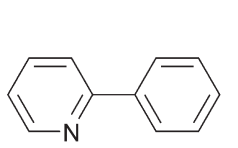

L1

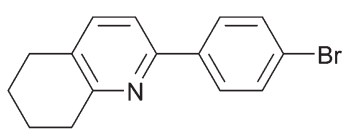

L3

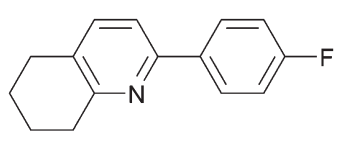

L4

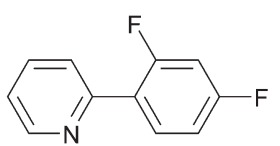

L2

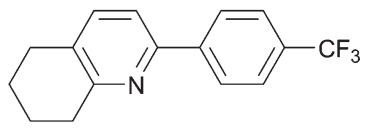

L5
Chart $1 \mathrm{C}^{\wedge} \mathrm{N}$ ligands $\mathbf{L 1}-\mathbf{L 5}$ used in order to subsequently prepare Pt(II) complexes 1-5.
$\mathrm{NH}_{2} \mathrm{OH} \cdot \mathrm{HCl}$ in order to form the individual target tetrahydroquinolines $^{25}$ L3-L5 (Scheme 1). The particular Mannich bases were prepared by aminomethylation of the respective phenylketone derivatives with $N, N$-dimethylmethyleneiminiumchlor$\operatorname{ide}^{27,28}$ (Scheme 1). The $\mathrm{C}^{\wedge} \mathrm{N}$ ligands $\mathbf{L 3}$-L5 were readily soluble in solvents of medium polarity. Their molecular weights were expectedly observed while the ${ }^{1} \mathrm{H}$ and ${ }^{13} \mathrm{C}$ NMR spectra revealed the characteristic pattern. Additionally, ligands L3-L5 were characterized by FT-IR spectroscopy and their bulk purity was furthermore confirmed by elemental analysis. Finally, five Pt(II) complexes 1-5 were synthesized (Scheme 2) by using a facile two step synthesis. ${ }^{1,5,6,12,29}$ Tailoring the Lewis method, ${ }^{29}$ the $\mathrm{C}^{\wedge} \mathrm{N}$ ligands $\mathbf{L 1}-\mathbf{L 5}$ (Chart 1) and $\mathrm{K}_{2} \mathrm{PtCl}_{4}$ were heated for $16 \mathrm{~h}$ in a mixture of 2-ethoxyethanol and water $(3: 1)$ at $80{ }^{\circ} \mathrm{C}$. The resulting $\mu$-chloro-bridged precursor dimers of complexes 1-5 were isolated in a yield of $68 \%$ to $84 \%$. In order to receive the dipivaloylmethane $\mathrm{Pt}$ (II) complexes $\mathbf{1 - 5}$, in yields of $36 \%$ to $79 \%$, the individual dimers were heated (3-6 h) with dipivaloylmethane, using $\mathrm{Na}_{2} \mathrm{CO}_{3}$ as a base, in 2-ethoxyethanol (Scheme 2). Note longer reaction times lead to significant formation of by-products. The Pt(II) complexes 1-5 were chromatographically purified over silica gel using dichloromethane and $n$-hexane $(1: 3 \mathrm{v} / \mathrm{v})$ and re-crystallized, correspondingly.

Complexes 1-5 were readily soluble in halogenated solvents like chloroform but also in $n$-hexane. In the ESI mass spectra the molecular ions $[\mathrm{M}+\mathrm{H}]^{+}(\mathrm{M}=$ neutral complexes $)$ were

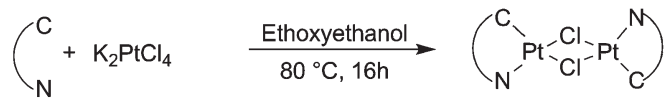

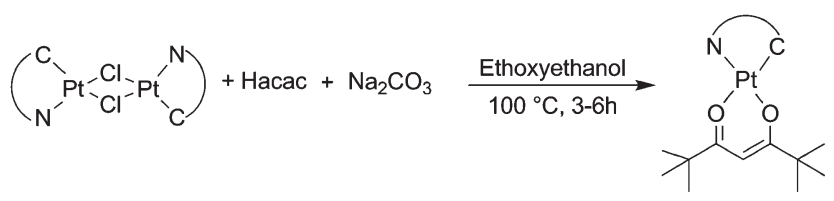

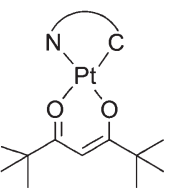

Scheme 2 Exemplified synthetic route from ligands L1-L5 via $\mu$-chloro-bridged precursor dimers 1-5 to Pt(II) complexes 1-5.<smiles>[X]c1ccc(C(=O)CCC2CCCCC2=O)cc1</smiles>

Scheme 1 Synthesis of 5,6,7,8-tetrahydroquinoline derivatives $\mathbf{L 3}-\mathbf{L 5}$ in yields of $\mathbf{L 3} 46 \%, \mathbf{L 4} 50 \%$ and $\mathbf{L 5} 54 \%$. X $=-\mathrm{Br}(\mathbf{L 3}),-\mathrm{F}(\mathbf{L 4}),-\mathrm{CF} 3$ (L5). 
expectedly observed at $\mathrm{m} / \mathrm{z} 533.2,569.2,666.1,605.2$ and 655.2. The ${ }^{1} \mathrm{H}$ and ${ }^{13} \mathrm{C}$ NMR spectra showed the characteristic pattern of the signals of ${ }^{t} \mathrm{Bu}$ from the dipivaloylmethane ancillary ligand at $1.23-1.31 \mathrm{ppm}$, and the olefinic proton at 5.83-5.90 ppm. For complexes 2, 4 and $5{ }^{19} \mathrm{~F}$ NMR confirmed likewise the aromatic fluorine and aromatic $-\mathrm{CF}_{3}$ resonances, respectively. Additionally, complexes $\mathbf{1}-\mathbf{5}$ were characterized by FT-IR spectroscopy and their purity was moreover affirmed by elemental analysis.

The UV-vis absorption and emission spectra of complexes 1-5 were recorded in $n$-hexane at a concentration of $1 \times$ $10^{-5} \mathrm{~mol} \mathrm{~L}^{-1}$ and are shown in Fig. 1 and 2, while the data are summarized in Table 1, correspondingly. The emission spectra

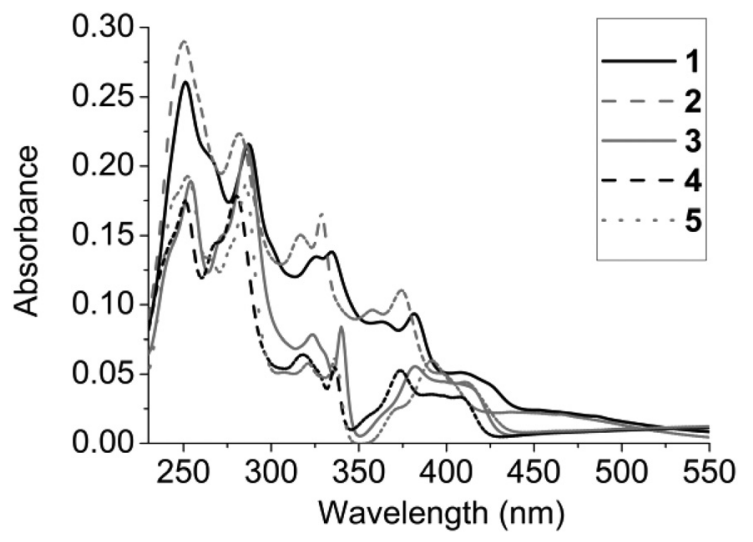

Fig. 1 UV-vis spectra of $\mathbf{1 - 5}$ in $n$-hexane solutions $(c=1 \times$ $10^{-5} \mathrm{~mol} \mathrm{~L}^{-1}$ ) at room temperature.

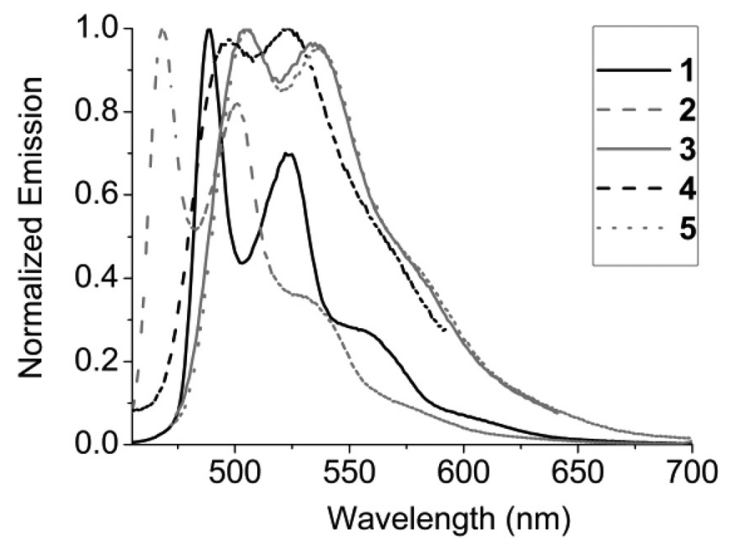

Fig. 2 Luminescence spectra of complexes 1-5 in $n$-hexane $(c=1 \times$ $\left.10^{-5} \mathrm{~mol} \mathrm{~L}^{-1}\right)$. of complexes 1-5 show a characteristic pattern of two maxima, ranging from the blue to the yellow spectral region (Table 1). The determined extinction coefficients of 3500-29000 and quantum efficiencies of $5.2-15.0 \%$ are comparable to those of similar complexes previously reported in the literature. ${ }^{12,30-33}$ The strong absorption for all complexes 1-5 at $225-345 \mathrm{~nm}$ can be related to spin-allowed ligand-centered transitions $\left(\pi \rightarrow \pi^{*}\right)$, which are the expected absorption bands in this region. ${ }^{18,34,35}$ Solvatochromatic metal-to-ligand charge transfer (MLCT) and ligand-to-ligand charge transfer (LLCT) transitions are located between 350 and $450 \mathrm{~nm}^{18,12}$

The $\beta$-diketonato ligand has no detectable influence on the luminescence properties of the excited state. ${ }^{1,5,6,12}$ The emission of the complexes 1-5 is due to a mixed ${ }^{3}$ LC-MLCT state ${ }^{12}$ and the particular effects of the respective $\mathrm{C}^{\wedge} \mathrm{N}$ substituents can directly be seen in the emission spectra (Fig. 2), correspondingly. Compared to complex 1, the fluoro-substituted complexes $\mathbf{2 , 4}$ and $\mathbf{5}$ demonstrate a blueshift; in contrast, the bromo-substituted complex 3 illustrates a redshift. Obviously, the $+I$ effect of the aliphatic ring is stronger than the $-I$ effect of the bromo-substituent. ${ }^{1,6,12}$ Thus, significant emission color tuning from blue through green to yellow has been achieved by varying the cyclometalating $\mathrm{C}^{\wedge} \mathrm{N}$ ligands and, more specifically, in case of the 5,6,7,8-tetrahydroquinoline derivatives $\mathbf{L 3}-\mathbf{L} \mathbf{5}$ by modifying the commercially available phenylketone-derivatives that have been used in order to prepare the Mannich base intermediates (Scheme 1).

\section{Pressure and temperature sensitivity}

The complexes 1-5 were incorporated into poly(styrene) (PS) films (thickness $6 \mu \mathrm{m}$ ) and their luminescence lifetimes (Table 1) were measured according the rapid lifetime determination (RLD) method. ${ }^{36,37}$ The lifetimes $\tau_{0}$ in absence of oxygen are usually not much affected by the polymer matrix, but it determines significantly the sensitivity of the luminophore to oxygen and temperature. ${ }^{38}$ Despite its limited oxygen permeability, PS is a standard polymer matrix for the characterization of oxygen and temperature sensitivities of quenchable probes. Thus, SternVolmer constants are available for many phosphorescent metalligand complexes for comparison. ${ }^{39}$

The light source for excitation is a $405 \mathrm{~nm}$ LED and the luminescence intensity is integrated in two precisely timed gates by a triggered CCD camera.

After a short light pulse, the luminescence intensity is acquired in the first gate $A_{1}$. Likewise, the intensity in the

Table 1 Photophysical data of Pt(II) complexes 1-5 in $n$-hexane $\left(c=1 \times 10^{-5} \mathrm{~mol} \mathrm{~L}^{-1}\right)$ at room temperature

\begin{tabular}{|c|c|c|c|c|}
\hline & UV-vis $(\mathrm{nm})\left\{\varepsilon\left(\mathrm{dm}^{3} \mathrm{~mol}^{-1} \mathrm{~cm}^{-1}\right)\right\}$ & $\lambda_{\text {max-em. }}(\mathrm{nm})$ & $\Phi(\%)$ & $\tau_{0}(\mu \mathrm{s})^{a}$ \\
\hline 1 & 251 (26 100), 287 (21 600), 326 (13 500), 335 (13 800), 363 (8700), 382 (9300), 408 (5100) & 488,524 & 15 & 5.7 \\
\hline 2 & 250 (29 000), 282 (22 400), 317 (15 000), 329 (16 500), 358 (9600), 374 (11 000) & 468,501 & 9.1 & 5.2 \\
\hline 4 & 251 (17 500), 280 (17 900), 318 (6400), 336 (5500), $374(5300), 391$ (3500) & 491,526 & 5.2 & 7.0 \\
\hline 5 & 252 (19300), 285 (18 600), 307 (5100), 337 (6100), 392 (6000), 410 (4400) & 501,538 & 6.9 & 5.8 \\
\hline
\end{tabular}




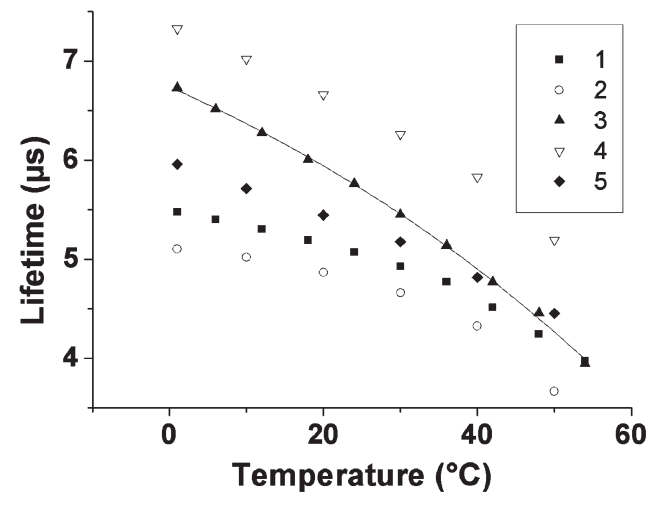

Fig. 3 Temperature dependence of the luminescence lifetime of the cyclometalated Pt(II) complexes ppy 1, 2,4-Fppy 2, Brph-thq 3, Fph-thq 4 and $\mathrm{CF}_{3}$ ph-thq $\mathbf{5}$ in PS at 1000 mbar air pressure. The values for Brph-thq are fitted according to eqn (3) for demonstration.

second gate $\mathrm{A}_{2}$ and the dark images are recorded. The whole imaging process has been described in previous works. ${ }^{40}$

The luminescence lifetime $(\tau)$ can be estimated according to eqn (1). ${ }^{41}$

$$
\tau=\frac{t_{2}-t_{1}}{\ln \left(\mathrm{A}_{1} / \mathrm{A}_{2}\right)}
$$

where $t_{1}$ and $t_{2}$ are delay times of the two gates $\mathrm{A}_{1}$ and $\mathrm{A}_{2}$ after the excitation pulse. However, this equation only gives correct lifetimes if the decay of luminescence is monoexponential and both time gates are of the same length. Usually, the condition of monoexponential decay is not fulfilled. Thus, only mean values of $\tau$ can be obtained with this simple process. But RLD is a valuable method to characterize relative changes of $\tau$ responding to luminescence quenching by oxygen or thermal quenching. The ratiometric measurement provides an intrinsically referenced signal, independent from variations in the intensity of the excitation light and other common interferences in luminescence measurements and, therefore, is more accurate than the detection of changes in luminescence intensity. All the imaging measurements were performed with square samples of $3 \times 3 \mathrm{~cm}$ size of the dyed PS films. The samples were fixed inside a calibration chamber, capable of holding air pressures from 50 to $2000 \mathrm{mbar}$ and temperatures from 1 to $60{ }^{\circ} \mathrm{C}$. A more detailed description of the chamber and the imaging setup is described in a previous publication. $^{5}$

The response of the luminescence of the studied complexes to increasing temperature is shown in Fig. 3. All measurements were performed using PS as the matrix polymer. It displays a moderate oxygen permeability $P$ of $1.9 \times 10^{-13} \mathrm{~cm}^{3}$ (STP) $\mathrm{cm}$ $\left(\mathrm{cm}^{2} \mathrm{~s} \mathrm{~Pa}\right)^{-1}(\mathrm{STP}=$ standard temperature and pressure $) .{ }^{42}$

In general, thermal quenching is observed for every luminescent dye. With increasing temperature the nonradiative relaxation rates are increasing. This is due to the Boltzmann distribution, which governs the population of the vibrational levels of the electronic states. At higher temperatures the deactivating states become thermally activated and the energy difference between the electronic states can be converted more easily into vibrational energy. The calibration plots for the temperature response are nonlinear and can be fitted by an Arrhenius-type equation

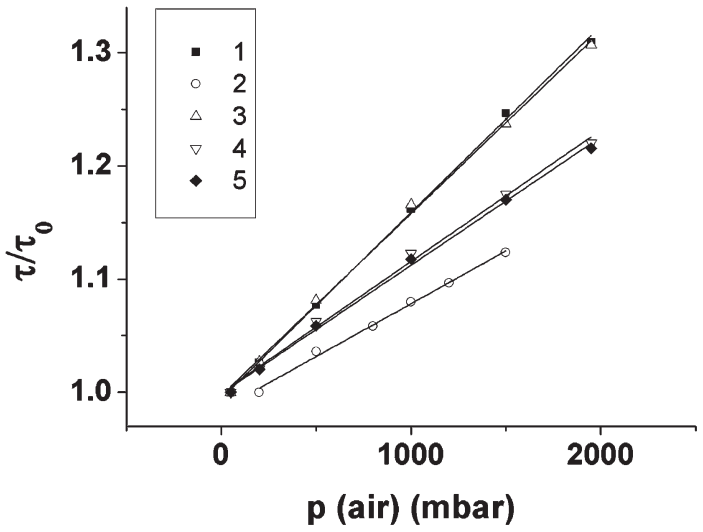

Fig. 4 Response of the luminescence lifetimes of ppy 1, 2,4-Fppy 2, Brph-thq 3, Fph-thq $\mathbf{4}$ and $\mathrm{CF}_{3}$ ph-thq $\mathbf{5}$ in PS to oxygen at a temperature of $30{ }^{\circ} \mathrm{C}$ displayed as Stern-Volmer plots with linear fits according to eqn (2). $\tau_{0}$ refers to the lifetime at $10 \mathrm{kPa} p \mathrm{O}_{2}$ and $30{ }^{\circ} \mathrm{C}$.

Table 2 Stern-Volmer constants $K_{\mathrm{SV}}$ and temperature coefficients of the cyclometalated $\mathrm{Pt}$ (II) complexes 1-5 in $6 \mu \mathrm{m}$ PS films

\begin{tabular}{lll}
\hline Complex & $K_{\mathrm{SV}}\left[10^{-4} \mathrm{mbar}^{-1}\right]^{b}$ & $T$-coeff. $\left[\% \tau \tau^{\circ} \mathrm{C}\right]^{a, b}$ \\
\hline $\mathbf{1}$ & 1.6 & 0.54 \\
$\mathbf{2}$ & 0.9 & 0.66 \\
$\mathbf{3}$ & 1.6 & 0.76 \\
$\mathbf{4}$ & 1.2 & 0.58 \\
$\mathbf{5}$ & 1.1 & 0.51 \\
${ }^{a}$ At $30{ }^{\circ} \mathrm{C}$ and 1000 mbar air pressure. ${ }^{b}$ In PS. \\
\hline
\end{tabular}

(eqn (2)), with $k_{0}$ as the temperature independent decay rate for the deactivation of the excited state, $k_{1}$ as the pre-exponential factor, and $\Delta E$ as the energy gap between emitting level and deactivating excited level. ${ }^{43}$ The temperature dependency of Brph-thq 3 is fitted exemplarily in Fig. 3.

$$
\frac{1}{\tau}=k_{0}+k_{1} \exp \left(-\frac{\Delta E}{R T}\right)
$$

The luminescence quenching of the Pt(II) emitters $\mathbf{1 - 5}$ by oxygen is depicted in Fig. 4 in the form of Stern-Volmer plots. The luminescence lifetime is proportional to partial oxygen pressure $\left(p \mathrm{O}_{2}\right)$ according to the Stern-Volmer equation (eqn (3)). The excited triplet state is deactivated by a collision with oxygen.

$$
\frac{I_{0}}{I}=\frac{\tau_{0}}{\tau}=1+K_{\mathrm{SV}}[Q]
$$

In this equation, $I_{0}$ is the luminescence intensity and $\tau_{0}$ the lifetime in the absence of quencher (oxygen). $I$ and $\tau$ are fluorescence intensity and lifetime, respectively, in the presence of an oxygen concentration of $[Q]$. The presence of oxygen quenches the luminescence lifetime and intensity likewise.

The Stern-Volmer constants $K_{\mathrm{SV}}$ and the temperature coefficients obtained from these measurements are shown in Table 2.

Generally, the oxygen sensitivity of the studied platinum complexes is very weak in contrast to other phosphorescent metal complexes such as platinum(II)-porphyrins, ${ }^{22,44,45}$ ruthenium(III), ${ }^{46}$ 


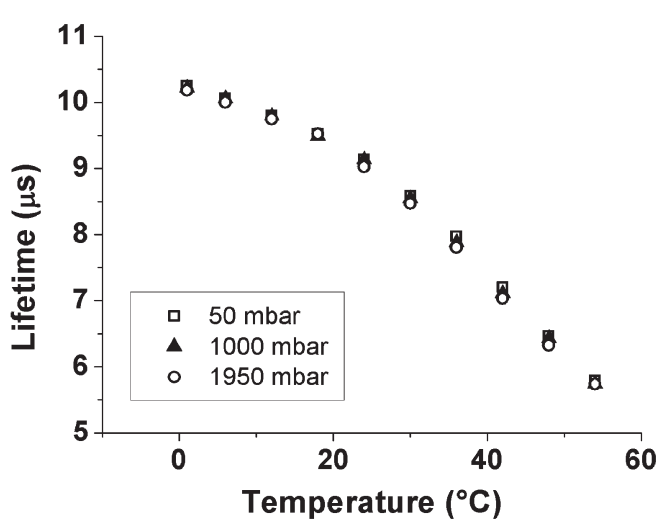

Fig. 5 Temperature dependence of the luminescence lifetime of Brphthq $\mathbf{3}$ in PVDCAN at various air pressures.

or some iridium(III) ${ }^{1,5,6}$ complexes characterized in PS. These represent typical luminescent oxygen indicators with SternVolmer constants that are significantly higher compared to the complexes presented here. The calculated lifetimes $\tau_{0}$ of the complexes are all in the same range around 5-7 $\mu$ s, thus, their Stern-Volmer constants are also alike within the accuracy of this determination method. With exception of 2,4-Fppy 2 and Brphthq $\mathbf{3}$, also thermal quenching is only very weakly pronounced. Hence, these luminophores are promising candidates for inert reference complexes that can be applied e.g. in optical sensors or for ratiometric dual-wavelength fluorescence measurements. Particularly, complex $\mathbf{4}$ and $\mathbf{5}$ are rather insensitive to either thermal or oxygen quenching. The latter can be further suppressed by incorporation in gas-blocking polymer materials. ${ }^{5,6}$

In terms of optical sensor applications, the complex $\mathbf{3}$ is interesting as a temperature-sensitive probe. Its temperature coefficient is almost as high as that of typical luminescent indicators for $T$ such as ruthenium and europium complexes. ${ }^{9,37}$ The advantage of this new $T$ probe compared to the frequently applied ruthenium complexes is that it is only marginally quenched by oxygen. Ruthenium probes always respond likewise to temperature and oxygen. Thus, $\mathbf{3}$ was incorporated in a gasblocking polymer matrix of poly(vinylidene chloride- $c o$-acrylonitrile) (PVDCAN). The results of the response to temperature are shown in Fig. 5.

It is evident that the resulting optical temperature sensor is virtually inert to oxygen quenching and exhibits a constant luminescence in a very broad air pressure range from 50 to 1950 mbar. In contrast to luminescent indicators for temperature based on ruthenium, ${ }^{41,47}$ europium,,${ }^{9,48}$ or iridium ${ }^{5,6}$ complexes, the emission of $\mathbf{3}$ is comparably short-wave, enabling a combination with a second red emitting indicator such as platinum(II)porphyrins for simultaneous detection of oxygen in dual sensors.

\section{Conclusions}

The synthesis and photophysical properties of a series of yellowgreen to blue-green light-emitting heteroleptic, cyclometalated $\left[\left(\mathrm{C}^{\wedge} \mathrm{N}\right) \mathrm{Pt}(\mathrm{II})(\mathrm{acac})\right]$ complexes is reported. The platinum(II) complexes are based on substituted phenylpyridine- and tetrahydroquinoline-type $\mathrm{C}^{\wedge} \mathrm{N}$ ligands and (Z)-5-hydroxy-2,2,6,6- tetramethylhept-4-en-3-one as ancillary ligand. Divergent to the commercial phenylpyridine-type ligands, ${ }^{12}$ the halogen-substituted tetrahydroquinoline ligands were available via a Mannich reaction leading to a series of novel Pt(II) complexes. The introduced complexes reveal lifetimes of several microseconds and quantum yields of up to $15 \%$. These luminescence intensities and lifetimes of the $\mathrm{Pt}(\mathrm{II})$ complex series were also studied with respect to their responses to oxygen and temperature. All addressed cyclometalated Pt(II) complexes show generally only a very low sensitivity to oxygen and temperature. Particularly, the insensitivity to oxygen quenching is unusual for phosphorescent metal-ligand complexes. Accordingly, these complexes are promising candidates to be used as inert reference dyes in optical sensors. However, the 2-(4-bromophenyl)-5,6,7,8-tetrahydroquinoline substituted $\mathrm{Pt}(\mathrm{II})$ complex was found to display a strong temperature quenching effect. This response to temperature was calibrated after incorporation in PVDCAN. The resulting greenemitting temperature sensor represents an appealing alternative to the available but mostly red light-emitting temperature-sensitive probes.

\section{Experimental section}

\section{General remarks}

All reagents were used as purchased from commercial suppliers without further purification. All reactions were carried out by using standard Schlenk techniques under an atmosphere of dry argon. Solvents were used as purchased without further purification. ${ }^{1} \mathrm{H}$ NMR and ${ }^{13} \mathrm{C}$ NMR spectra were performed on a BRUKER ARX 125, ARX 200 and ARX 500 as well as on a BRUKER III AVANCE 600; ${ }^{19} \mathrm{~F}$ NMR spectra were performed on a BRUKER AVANCE 400. Chemical shifts were quoted relative to the internal standard tetramethylsilane $\left(\mathrm{Me}_{4} \mathrm{Si}\right)$ in $\mathrm{CDCl}_{3}$ solutions. For ${ }^{1} \mathrm{H}(\mathrm{s}=$ singlet, $\mathrm{d}=$ doublet, $\mathrm{t}=$ triplet, $\mathrm{q}=$ quartet and $\mathrm{m}=$ multiplet), ${ }^{13} \mathrm{C}$ NMR data, $J$ values are given in Hertz $(\mathrm{Hz})$. Mass spectrometry was carried out by using electron impact (EI, $70 \mathrm{eV}$ ) and electrospray ionization (ESI) techniques on a Finnigan MAT 8230 and a Bruker Daltonics MICROTOF instrument, respectively. Fourier transform infrared (FT-IR) spectra were recorded on a JASCO FT/IR-4200 as well as on a Nicolet 510 P FT-IR spectrometer. Elemental analysis (EA) was performed on a Perkin Elmer $240 \mathrm{~B}$ and on a HEKAtech EuroEA 3000 (CHNS) setup, correspondingly. UV-vis spectra were measured with a JASCO V-550 UV-vis spectrometer $(1 \mathrm{~cm}$ cuvettes) at concentrations of $1 \times 10^{-5} \mathrm{~mol} \mathrm{~L}^{-1}$. The emission spectra were performed using a CARY Eclipse fluorescence spectrophotometer at concentrations of $1 \times 10^{-5} \mathrm{~mol} \mathrm{~L}^{-1}$. Absorption and emission spectra for the determination of pressure and temperature sensitivity were recorded on a Lambda $14 \mathrm{p}$ Perkin-Elmer UV-vis spectrophotometer (Waltham, MA, USA, www.perkinelmer.com) and an Aminco AB 2 luminescence spectrometer (Thermo Scientific Inc., Waltham, MA, USA, www.thermo.com), respectively. The $p / T$ calibration chamber was provided by the German Aerospace Center (DLR) in Göttingen. ${ }^{9}$ All time-resolved measurements were performed with a PCO SensiCam 12 bit b/w CCD camera (PCO, Kelheim, Germany, www.pco.de) equipped with a Schneider-Kreuznach Xenon 0.95/17 lens (Jos. Schneider Optische Werke, Bad 
Kreuznach, Germany, www.schneiderkreuznach.com) and a 405-66-60 405 nm LED from Roithner Lasertechnik (Vienna, Austria, www.roithner-laser.com). The excitation light was focused by a PCX 18_18 MgF2 TS lens from Edmund Optics (Karlsruhe, Germany, www.edmundoptics.com). It was filtered through a BG 12 filter (Schott, Mainz, Germany, www.schott. com) with a thickness of $2 \mathrm{~mm}$. Emission was detected through a GG 475 high pass filter purchased from AHF Analysentechnik (www.ahf.de). The PS films and the PVDCAN films containing the $\mathrm{Pt}$ (II) complexes 1-5 were prepared with a knife coating device on a solid poly(ethylene terephtalate) (PET) support. The concentration of the polymer solutions was $5 \%(\mathrm{w} / \mathrm{w})$ in THF. The polymers were purchased from Sigma-Aldrich (www.sigmaaldrich.com). In order to increase the luminescence intensity recorded by the camera, the backside of the PET foils was coated with a highly reflective layer of $\mathrm{TiO}_{2}$ in silicone. Chromatography: Separations were carried out on Geduran Si 60 (0.063-0.200 mm). Thin layer chromatography (TLC) was performed on Analtech uniplate silica gel GF plates (500 micron, $20 \times 20 \mathrm{~cm}$ ) and developed with ( $n$-hexane-ethyl acetate: $10: 3$ ).

Methyleniminiumchloride, ${ }^{27,28}$ the enamine ${ }^{49}$ and 1-morpholinocyclohexene, ${ }^{26}$ as well as the dimers ${ }^{29} \mathbf{1}$ and $\mathbf{2}$ and complexes $^{12} \mathbf{1}$ and $\mathbf{2}$ were synthesized according to partly modified literature procedures.

Synthesis of $N, N, N^{\prime}, N^{\prime}$-tetramethylmethanediamine. Dimethylamine $(40 \%, 45 \mathrm{~mL}, 0.4 \mathrm{~mol})$ was added drop-wise to a stirred ice cooled solution of formaldehyde $(37 \%, 15 \mathrm{~mL}, 0.2 \mathrm{~mol})$. Yield: $16.7 \mathrm{~g}\left(81 \%\right.$ ), bp.: $82{ }^{\circ} \mathrm{C}$ (Lit. ${ }^{50}$ Yield: $85 \%$, bp.: 81.5-83 $\left.{ }^{\circ} \mathrm{C}\right) .{ }^{1} \mathrm{H}$ NMR $\left(200 \mathrm{MHz}, \mathrm{CDCl}_{3}\right): \delta=2.23(\mathrm{~s}, 12 \mathrm{H}$, $\left.\mathrm{N}\left(\mathrm{CH}_{3}\right)_{2}\right), 2.72\left(\mathrm{~s}, 2 \mathrm{H}, \mathrm{CH}_{2}\right)$.

Synthesis of $\mathbf{N}, \mathbf{N}$-dimethyliminiumchloride. Acetylchloride $(8.5 \mathrm{ml}, 0.12 \mathrm{~mol})$ in diethylether $(50 \mathrm{~mL})$ was added drop-wise to a ice cooled suspension of $N, N, N^{\prime}, N^{\prime}$-tetramethylmethanediamine $(10.2 \mathrm{~g}, 0.10 \mathrm{~mol})$. The mixture was stirred overnight at room temperature. The iminium salt was rapidly filtrated, washed with diethyl ether and then dried under vacuum. Yield: $8.4 \mathrm{~g}$ (90\%) (Lit. ${ }^{51}$ Yield: 92\%). ${ }^{1} \mathrm{H}$ NMR (200 MHz, $\left.\mathrm{CDCl}_{3}\right): \delta=$ $3.79\left(\mathrm{~s}, 6 \mathrm{H}, \mathrm{N}\left(\mathrm{CH}_{3}\right)_{2}\right), 8.49\left(\mathrm{~s}, 2 \mathrm{H}, \mathrm{CH}_{2}=\mathrm{N}\right)$.

\section{General procedure for the Mannich bases ${ }^{25}$}

The ketone $(10 \mathrm{mmol})$ and $N, N$-dimethyliminiumchloride (10 mmol) were refluxed in abs. acetonitrile $(25 \mathrm{~mL})$ for $3-4 \mathrm{~h}$ under dry conditions. The Mannich base was filtrated after cooling down in the fridge and dried under vacuum.

Synthesis of dimethyl-(3-oxo-3-(4-bromophenyl))propylammoniumchloride. 4'-Bromoacetophenone (9.96 g, $50 \mathrm{mmol})$ and $N, N$-dimethyliminiumchloride $(4.69 \mathrm{~g}, 50 \mathrm{mmol})$. Yield: $8.38 \mathrm{~g}$ (57\%) colorless crystals. Bp.: $194.6^{\circ} \mathrm{C}$ (Lit. $\left.{ }^{52}: 200.5-201.5^{\circ} \mathrm{C}\right)$. ${ }^{1} \mathrm{H}$ NMR $\left(500 \mathrm{MHz}, \mathrm{CDCl}_{3}-\mathrm{MeOD}\right): \delta=2.80(\mathrm{~s}, 6 \mathrm{H})$, $3.41-3.46(\mathrm{t}, 2 \mathrm{H}), 3.56-3.61(\mathrm{t}, 2 \mathrm{H}), 7.54-7.58\left(\mathrm{~d},{ }^{3} J=8.5 \mathrm{~Hz}\right.$, 2H), 7.79-7.83 (d, $\left.{ }^{3} J=8.5 \mathrm{~Hz}, 2 \mathrm{H}\right)$.

Synthesis of dimethyl-(3-oxo-3-(4-fluorophenyl))propylammoniumchloride. 4-Fluoroacetophenone $(500 \mathrm{mg}, 3.6 \mathrm{mmol})$ and $339 \mathrm{mg}$ (3.6 mmol) N,N-dimethyliminiumchloride. Yield:
$740 \mathrm{mg}(89 \%)$ colorless solid. ${ }^{1} \mathrm{H}$ NMR (500 $\left.\mathrm{MHz}, \mathrm{CDCl}_{3}\right): \delta=$ $2.85(\mathrm{~s}, 6 \mathrm{H}), 3.48-3.53(\mathrm{t}, 2 \mathrm{H}), 3.72-3.76(\mathrm{t}, 2 \mathrm{H}), 7.12-7.18(\mathrm{~m}$, $\left.{ }^{3} J_{\mathrm{H}, \mathrm{F}}=9.0 \mathrm{~Hz}, 2 \mathrm{H}\right), 8.01-8.06\left(\mathrm{~m},{ }^{4} J_{\mathrm{H}, \mathrm{F}}=5.5 \mathrm{~Hz}, 2 \mathrm{H}\right)$, $12.62-12.88$ (bs, $1 \mathrm{H})$.

Synthesis of dimethyl-(3-0xo-3-(4-trifluoromethylphenyl))propylammoniumchloride. 4-(Trifluoromethyl)acetophenone $5.0 \mathrm{~g}$ (26.5 mmol) and $N, N$-dimethyliminiumchloride $(2.5 \mathrm{~g}$, $26.5 \mathrm{mmol})$. Yield: $4.32 \mathrm{~g}(58 \%)$ colorless solid. ${ }^{1} \mathrm{H}$ NMR $\left(500 \mathrm{MHz}, \mathrm{CDCl}_{3}\right): \delta=2.87(\mathrm{~s}, 6 \mathrm{H}), 3.50-3.57(\mathrm{t}, 2 \mathrm{H})$, $3.80-3.84(\mathrm{t}, 2 \mathrm{H}), 7.85-7.90\left(\mathrm{~m},{ }^{3} \mathrm{~J}=8.0 \mathrm{~Hz}, 2 \mathrm{H}\right), 8.11-8.16$ $\left(\mathrm{m},{ }^{3} J=8.0 \mathrm{~Hz}, 2 \mathrm{H}\right), 12.54-12.72$ (bs, $\left.1 \mathrm{H}\right)$.

\section{General procedure for the diketones ${ }^{25}$}

The enamine $(0.1 \mathrm{~mol})$ and the Mannich base $(0.1 \mathrm{~mol})$ were stirred in abs. dioxane $(100 \mathrm{~mL})$ for $16 \mathrm{~h}$ under reflux. After adding distilled water $(30 \mathrm{~mL})$ the mixture was heated for $1 \mathrm{~h}$. The mixture cooled and water $(30 \mathrm{~mL})$ was added and extracted with dichloromethane $(4 \times 40 \mathrm{~mL})$. The organic layers were combined and washed with diluted hydrochloric acid $(20 \mathrm{~mL})$ and water.

Synthesis of 2-(3-oxo-3-(4-bromophenyl)-propyl)cyclohexanone. Dimethyl-(3-oxo-3-(4-bromophenyl))propylammoniumchloride $(6.04 \mathrm{~g}, 20.7 \mathrm{mmol})$ and 1-morpholinocyclohexene (3.5 g, $20.7 \mathrm{mmol})$. Yield: $4.17 \mathrm{~g}(65 \%)$ brown oil. ${ }^{1} \mathrm{H}$ NMR $\left(500 \mathrm{MHz}, \mathrm{CDCl}_{3}\right): \delta=1.32-1.48(\mathrm{~m}, 1 \mathrm{H}), 1.58-1.71(\mathrm{~m}, 3 \mathrm{H})$, $1.79-1.88(\mathrm{~m}, 2 \mathrm{H}), 1.99-2.14(\mathrm{~m}, 3 \mathrm{H}), 2.21-2.44(\mathrm{~m}, 2 \mathrm{H})$, $2.82-3.10(\mathrm{~m}, 2 \mathrm{H}), 7.53-7.57\left(\mathrm{~d},{ }^{3} \mathrm{~J}=8.5 \mathrm{~Hz}, 2 \mathrm{H}\right), 7.79-7.82$ $\left(\mathrm{d},{ }^{3} \mathrm{~J}=8.5 \mathrm{~Hz}, 2 \mathrm{H}\right) .{ }^{13} \mathrm{C} \mathrm{NMR}\left(125 \mathrm{MHz}, \mathrm{CDCl}_{3}\right): \delta=24.56$ $(\mathrm{t}), 25.09(\mathrm{t}), 28.08(\mathrm{t}), 34.60(\mathrm{t}), 36.36(\mathrm{t}), 42.23(\mathrm{t}), 49.94$ (d), 128.08 (s), 129.67 (d), 131.84 (d), 135.58 (s), 199.19 (s), $213.04(\mathrm{~s})$.

Synthesis of 2-(3-oxo-3-(4-fluorophenyl)-propyl)cyclohexanone. Dimethyl-(3-oxo-3-(4-fluorophenyl))propylammoniumchloride $(740 \mathrm{mg}, 3.2 \mathrm{mmol})$ and $(530 \mathrm{mg}, 3.2 \mathrm{mmol})$ enamine 1-morpholinocyclohexene. Yield: $128 \mathrm{mg}(16 \%)$ yellow oil after purification by column chromatography on silica gel $\left(\mathrm{CH}_{2} \mathrm{Cl}_{2}-\right.$ $\mathrm{Et}_{2} \mathrm{O} 1: 1$ as eluent). ${ }^{1} \mathrm{H}$ NMR (500 $\left.\mathrm{MHz}, \mathrm{CDCl}_{3}\right): \delta=$ $1.39-1.50(\mathrm{~m}, 1 \mathrm{H}), 1.61-1.73(\mathrm{~m}, 3 \mathrm{H}), 1.83-1.89(\mathrm{~m}, 1 \mathrm{H})$, 2.02-2.17 (m, 3H), 2.26-2.34 (m, 1H), 2.36-2.46 (m, 2H), 2.87-2.96 (m, 1H), 3.04-3.14 (m, 1H), 7.07-7.13 (t, 2H), 7.97-8.03 (m, $\left.{ }^{3} J_{\mathrm{H}, \mathrm{F}}=9.0 \mathrm{~Hz}, 2 \mathrm{H}\right) .{ }^{13} \mathrm{C} \mathrm{NMR}(125 \mathrm{MHz}$, $\left.\mathrm{CDCl}_{3}\right): \delta=24.66(\mathrm{t}), 25.09(\mathrm{t}), 28.10(\mathrm{t}), 34.62(\mathrm{t}), 36.33(\mathrm{t})$, $42.25(\mathrm{t}), 49.98(\mathrm{~d}), 115.60\left(\mathrm{~d},{ }^{2} J_{\mathrm{C}, \mathrm{F}}=20 \mathrm{~Hz}\right), 130.75\left(\mathrm{~d},{ }^{3} J_{\mathrm{C}, \mathrm{F}}=\right.$ $8 \mathrm{~Hz}), 133.33\left(\mathrm{~d},{ }^{4} J_{\mathrm{C}, \mathrm{F}}=3 \mathrm{~Hz}\right), 165.69\left(\mathrm{~d},{ }^{1} J_{\mathrm{C}, \mathrm{F}}=245 \mathrm{~Hz}\right)$, 198.67 (s), 213.10 (s).

Synthesis of 2-(3-oxo-3-(4-trifluoromethylphenyl)-propyl)cyclohexanone. Dimethyl-(3-oxo-3-(4-trifluoromethylphenyl))propylammoniumchloride $(4.1 \mathrm{~g}, 22 \mathrm{mmol})$ and 1-morpholinocyclohexene (3.6 g, $22 \mathrm{mmol})$. Yield: $2.0 \mathrm{~g}$ (30\%) pale yellow solid after purification by column chromatography on silica gel $\left(\mathrm{CH}_{2} \mathrm{Cl}_{2}-\mathrm{Et}_{2} \mathrm{O} 1: 1\right.$ as eluent). ${ }^{1} \mathrm{H} \mathrm{NMR}\left(500 \mathrm{MHz}, \mathrm{CDCl}_{3}\right): \delta=$ $1.34-1.44(\mathrm{~m}, 1 \mathrm{H}), 1.55-1.68(\mathrm{~m}, 3 \mathrm{H}), 1.74-1.84(\mathrm{~m}, 1 \mathrm{H})$, 1.95-2.10 (m, 3H), 2.20-2.28 (m, 1H), 2.28-2.43 (m, 2H), 2.87-2.95 (m, 1H), 3.04-3.12 (m, 1H), 7.61-7.65 (d, ${ }^{3} J=8.0 \mathrm{~Hz}$, $2 \mathrm{H}), 7.98-8.03\left(\mathrm{~d},{ }^{3} \mathrm{~J}=8.0 \mathrm{~Hz}, 2 \mathrm{H}\right) .{ }^{13} \mathrm{C} \mathrm{NMR}(125 \mathrm{MHz}$, 
$\left.\mathrm{CDCl}_{3}\right): \delta=24.39(\mathrm{t}), 25.04(\mathrm{t}), 27.99(\mathrm{t}), 34.52(\mathrm{t}), 36.65(\mathrm{t})$, $42.15(\mathrm{t}), 49.81(\mathrm{~d}), 123.59\left(\mathrm{q},{ }^{1} J_{\mathrm{C}, \mathrm{F}}=272 \mathrm{~Hz}\right), 125.52\left(\mathrm{q},{ }^{3} J_{\mathrm{C}, \mathrm{F}}\right.$ $=4 \mathrm{~Hz}), 128.38\left({ }^{4} J_{\mathrm{C}, \mathrm{F}}=1 \mathrm{~Hz}\right), 134.10\left(\mathrm{q},{ }^{2} J_{\mathrm{C}, \mathrm{F}}=32 \mathrm{~Hz}\right)$, 139.49 (s), 199.06 (s), 212.77 (s).

\section{General procedure for the functionalized $C^{\wedge} N$ ligands $L 3-L^{25}$}

The diketone $(10 \mathrm{mmol})$ and the hydroxylamine hydrochloride $(10 \mathrm{mmol})$ were stirred in ethanol $(10 \mathrm{~mL})$ overnight under reflux. The reaction mixture was subsequently cooled down to room temperature, neutralized with $\mathrm{Na}_{2} \mathrm{CO}_{3}$, mixed with water $(50 \mathrm{~mL})$ and extracted with dichloromethane $(4 \times 30 \mathrm{~mL})$. The organic layers were dried over $\mathrm{Na}_{2} \mathrm{SO}_{4}$ and evaporated. The crude product was purified by column chromatography.

Synthesis of 2-(4-bromophenyl)-5,6,7,8-tetrahydroquinoline. 2-(3-Oxo-3-(4-bromophenyl)propyl)cyclohexanone $(3.0 \mathrm{~g}$, $4.4 \mathrm{mmol})$ and $\mathrm{NH}_{2} \mathrm{OH} \cdot \mathrm{HCl}(674 \mathrm{mg}, 9.7 \mathrm{mmol})$. Yield: $1.27 \mathrm{~g}$ (46\%) yellow solid after purification by column chromatography on silica gel $\left(\mathrm{CH}_{2} \mathrm{Cl}_{2}\right.$ as eluent). Bp.: $114.5{ }^{\circ} \mathrm{C}$ (Lit. $\left.{ }^{27}: 109{ }^{\circ} \mathrm{C}\right)$. ${ }^{1} \mathrm{H}$ NMR $\left(500 \mathrm{MHz}, \mathrm{CDCl}_{3}\right): \delta=1.79-1.85(\mathrm{~m}, 2 \mathrm{H}), 1.88-1.94$ $(\mathrm{m}, 2 \mathrm{H}), 2.74-2.79(\mathrm{t}, 2 \mathrm{H}), 2.96-3.00(\mathrm{t}, 2 \mathrm{H}), 7.34-7.39(\mathrm{~m}$, 2H), 7.52-7.55 (m, 2H), 7.81-7.84 (m, 2H). ${ }^{13} \mathrm{C}$ NMR $\left(125 \mathrm{MHz}, \mathrm{CDCl}_{3}\right): \delta=22.79(\mathrm{t}), 23.20(\mathrm{t}), 28.59(\mathrm{t}), 32.85(\mathrm{t})$, 117.53 (d), 122.75 (s), 128.37 (d), 131.17 (s), 131.70 (d), 137.51 (d), $138.72(\mathrm{~s}), 153.22(\mathrm{~s}), 157.41(\mathrm{~s})$. IR $(\mathrm{KBr}): v\left(\mathrm{~cm}^{-1}\right)=$ 2929, 2859, 2360, 2343, 1683, 1653, 1575, 1560, 1541, 1510, $1487,1456,1256,1131,1068,1005,806,743$. MS $(70 \mathrm{eV}): \mathrm{m} / \mathrm{z}$ $(\%)=289$ (97), 288 (54), 287 (100), 261 (13), 208 (5), 180 (10), 77 (6). $\mathrm{C}_{15} \mathrm{H}_{14} \mathrm{BrN}$ (287.03): calcd $\mathrm{C}$ 62.52, H 4.90, N 4.86; found $\mathrm{C} 62.29, \mathrm{H} 4.40, \mathrm{~N} 4.87$.

Synthesis of 2-(4-fluorophenyl)-5,6,7,8-tetrahydroquinoline. 2-(3-Oxo-3-(4-fluorophenyl)propyl)cyclohexanone $\quad(2.4 \mathrm{~g}$, $4.8 \mathrm{mmol})$ and $\mathrm{NH}_{2} \mathrm{OH} \cdot \mathrm{HCl}(672 \mathrm{mg}, 4.8 \mathrm{mmol})$. Yield: $1.1 \mathrm{~g}$ $(50 \%)$ yellow oil after purification by column chromatography on silica gel (petrol ether- $\mathrm{Et}_{2} \mathrm{O} 6: 1$ as eluent). ${ }^{1} \mathrm{H}$ NMR $\left(500 \mathrm{MHz}, \mathrm{CDCl}_{3}\right): \delta=1.81-1.86(\mathrm{~m}, 2 \mathrm{H}), 1.90-1.95(\mathrm{~m}, 2 \mathrm{H})$, 2.77-2.81 (t, 2H), 2.96-3.00 (t, 2H), 7.09-7.14 (m, ${ }^{3} J_{\mathrm{H}, \mathrm{F}}=9.0$ $\mathrm{Hz}, 2 \mathrm{H}), 7.39-7.40(\mathrm{~s}, 2 \mathrm{H}), 7.91-7.95\left(\mathrm{~m},{ }^{4} J_{\mathrm{H}, \mathrm{F}}=5.5 \mathrm{~Hz}, 2 \mathrm{H}\right)$. ${ }^{13} \mathrm{C}$ NMR (125 MHz, $\left.\mathrm{CDCl}_{3}\right): \delta=22.79(\mathrm{t}), 23.19(\mathrm{t}), 28.52$ (t), 32.83 (t), 115.37 (d), 115.54 (d), 117.53 (d), 128.50 (d), 128.57 (d), 130.69 (s), 136.08 (s), 137.47 (d), 153.63 (s), 157.31 (s), $163.22\left(\mathrm{~d},{ }^{1} J_{\mathrm{C}, \mathrm{F}}=255 \mathrm{~Hz}\right)$. IR $(\mathrm{KBr}): v\left(\mathrm{~cm}^{-1}\right)=3068$, 3048, 3018, 2934, 2880, 2860, 2835, 1684, 1600, 1589, 1570, $1511,1458,1433,1419,1388,1355,1293,1230,1185,1159$, 1126, 1096, 1048, 1015, 989, 938, 849, 834, 812, 749, 668, 557, 520, 483. MS (70 eV): $m / z(\%)=228(67), 229(6), 227$ (100), 226 (92), 199 (70), 133 (19), 77 (10). $\mathrm{C}_{15} \mathrm{H}_{14} \mathrm{FN}$ (227.11): calcd C 79.27, H 6.21, N 6.16; found C 79.35, H 7.31, N 6.54.

Synthesis of 2-(4-trifluoromethylphenyl)-5,6,7,8-tetrahydroquinoline. 2-(3-Oxo-3-(4-trifluoromethylphenyl)propyl)cyclohexanone $(2.68 \mathrm{~g}, 9 \mathrm{mmol})$ and $\mathrm{NH}_{2} \mathrm{OH} \cdot \mathrm{HCl}(626 \mathrm{mg}$, $9 \mathrm{mmol})$. Yield: $1.35 \mathrm{~g}(54 \%)$ yellow oil after purification by column chromatography on silica gel (petrol ether- $\mathrm{Et}_{2} \mathrm{O} 6: 1$ as eluent). ${ }^{1} \mathrm{H}$ NMR (500 MHz, $\left.\mathrm{CDCl}_{3}\right): \delta=1.81-1.89(\mathrm{~m}, 2 \mathrm{H})$, 1.90-1.98 (m, 2H), 2.79-2.84 (t, 2H), 2.97-3.03 (t, 2H), $7.42-7.50\left(\mathrm{q},{ }^{3} J=8.0 \mathrm{~Hz}, 2 \mathrm{H}\right), 7.67-7.70\left(\mathrm{~d},{ }^{3} J=8.0 \mathrm{~Hz}, 2 \mathrm{H}\right)$, 8.05-8.09 (d, $\left.{ }^{3} J=8.0 \mathrm{~Hz}, 2 \mathrm{H}\right) .{ }^{13} \mathrm{C} \mathrm{NMR}\left(125 \mathrm{MHz}, \mathrm{CDCl}_{3}\right)$ : $\delta=22.72(\mathrm{t}), 23.13(\mathrm{t}), 28.60(\mathrm{t}), 32.83(\mathrm{t}), 118.08(\mathrm{~d}), 124.31$ $\left(\mathrm{q},{ }^{1} J_{\mathrm{C}, \mathrm{F}}=272 \mathrm{~Hz}\right), 125.54\left(\mathrm{q},{ }^{3} J_{\mathrm{C}, \mathrm{F}}=4 \mathrm{~Hz}\right), 127.03(\mathrm{~d}), 130.24$ $\left(\mathrm{q},{ }^{2} J_{\mathrm{C}, \mathrm{F}}=32 \mathrm{~Hz}\right), 131.80(\mathrm{~s}), 137.54\left(\mathrm{~d},{ }^{4} J_{\mathrm{C}, \mathrm{F}}=1 \mathrm{~Hz}\right)$, 143.22 (s), 152.99 (s), $157.71(\mathrm{~s})$. IR (KBr): $v\left(\mathrm{~cm}^{-1}\right)=2942$, 2867, 2361, 1688, 1620, 1569, 1460, 1329, 1255, 1164, $1124,1067,1015,856,833,810,599$. MS $(70 \mathrm{eV}): \mathrm{m} / z(\%)=$ 279 (1), 278 (15), 277 (100), 249 (17), 180 (3). $\mathrm{C}_{16} \mathrm{H}_{14} \mathrm{~F}_{3} \mathrm{~N}$ (277.11): calcd C 69.30, H 5.09, N 5.05; found C 69.13, H 4.41, N 5.00.

\section{General procedure for the $\mathrm{Pt}(\mathrm{II})-\mu$-dichloro-bridged dimers $1,5,6,12,29$}

$\mathrm{K}_{2} \mathrm{PtCl}_{4}$ and ligand $\mathrm{HC}^{\wedge} \mathrm{N}$ (2.2 equiv.) was stirred in a Schlenk flask for $16 \mathrm{~h}$ at $80{ }^{\circ} \mathrm{C}$ in a mixed solution of 2-ethoxyethanol and water $(3: 1)$. After cooling down to room temperature, the respective dimeric complexes were isolated in water, filtered, and washed with water and ethanol. The precursor complexes were dried under reduced pressure.

Dimer 1. ${ }^{12,29}$ 2-Phenylpyridine (400 $\mathrm{mg}, 2.577 \mathrm{mmol}$ ) and $\mathrm{K}_{2} \mathrm{PtCl}_{4}$ (486 mg, $1.171 \mathrm{mmol}$ ). Yield: $325 \mathrm{mg}$ (72\%) yellow green powder.

Dimer 2. ${ }^{12}$ 2,4-Difluorophenylpyridine (442 mg, $2.312 \mathrm{mmol}$ ) and $\mathrm{K}_{2} \mathrm{PtCl}_{4}$ (441 mg, $\left.1.051 \mathrm{mmol}\right)$. Yield: $356 \mathrm{mg}(80 \%)$ yellow green powder.

Dimer 3. 2-(4-Bromophenyl)-5,6,7,8-tetrahydroquinoline (697 mg, $2.420 \mathrm{mmol}$ ) and $\mathrm{K}_{2} \mathrm{PtCl}_{4}(457 \mathrm{mg}, 1.100 \mathrm{mmol})$. Yield: $480 \mathrm{mg}(84 \%)$ dark green powder.

Dimer 4. 2-(4-Fluorophenyl)-5,6,7,8-tetrahydroquinoline (214 mg, $0.942 \mathrm{mmol})$ and $\mathrm{K}_{2} \mathrm{PtCl}_{4}(178 \mathrm{mg}, 0.428 \mathrm{mmol})$. Yield: 137 (70\%) dark green powder.

Dimer 5. 2-(4-Trifluoromethylphenyl)-5,6,7,8-tetrahydroquinoline $(212 \mathrm{mg}, 0.765 \mathrm{mmol})$ and $\mathrm{K}_{2} \mathrm{PtCl}_{4}$ (144 $\mathrm{mg}$, $0.347 \mathrm{mmol})$. Yield: $120 \mathrm{mg}(68 \%)$ yellow green powder.

\section{General procedure for the Pt(II) complexes ${ }^{1,5,6,12}$}

The particular dimers were stirred in a Schlenk flask with dipivaloylmethane (3 equiv.) and $\mathrm{Na}_{2} \mathrm{CO}_{3}$ (10 equiv.) in 2-ethoxyethanol at $80{ }^{\circ} \mathrm{C}$ for $3-6 \mathrm{~h}$. The residue was filtered, purified using thin layer chromatography ( $n$-hexane-ethyl acetate) or column chromatography $\left(\mathrm{CH}_{2} \mathrm{Cl}_{2}-n\right.$-hexane $)$ and re-crystallized, correspondingly.

\section{Complex 1. ${ }^{12}$}

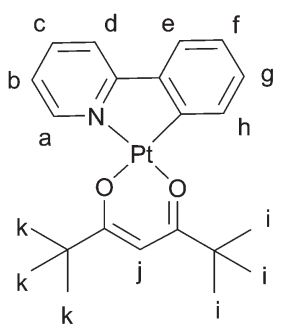


Dimer 1 (311 mg, $0.405 \mathrm{mmol}$ ), 2,2,6,6-tetramethyl-3,5-heptanedione (166 mg, $0.903 \mathrm{mmol}$ ) and $\mathrm{Na}_{2} \mathrm{CO}_{3}(319 \mathrm{mg}$, $3.01 \mathrm{mmol}$ ). After purification by column chromatography on silica gel $\left(\mathrm{CH}_{2} \mathrm{Cl}_{2}-n\right.$-hexane $1: 3$ as eluent) yellow crystals (252 mg, 58\%) (Found: C 50.06, H 5.37, N 2.52. $\mathrm{C}_{22} \mathrm{H}_{27} \mathrm{NO}_{2} \mathrm{Pt}$ requires $\mathrm{C} 49.62, \mathrm{H} 5.11, \mathrm{~N} 2.63) ; v_{\max } / \mathrm{cm}^{-1} 3106,3045,2952$, 2919, 2855, 2352, 1731, 1605, 1583, 1523, 1487, 1458, 1308, $1272,1243,1218,1181,1139,1066,1023,1010,952,930,873$, 822, 787, 740, 722, 658 and $629 ;{ }^{1} \mathrm{H}$ NMR $\left(600 \mathrm{MHz} ; \mathrm{CDCl}_{3}\right.$; $\left.\mathrm{Me}_{4} \mathrm{Si}\right) 1.30^{\mathrm{k}}\left(\mathrm{s}, 9 \mathrm{H}, \mathrm{CH}_{3}\right), 1.31^{\mathrm{i}}\left(\mathrm{s}, 9 \mathrm{H}, \mathrm{CH}_{3}\right), 5.83^{\mathrm{j}}(\mathrm{s}, 1 \mathrm{H}$, $\mathrm{CH}), 7.06-8.18^{\mathrm{b}, \mathrm{g}}(\mathrm{m}, 2 \mathrm{H}, \mathrm{ArH}), 7.23^{\mathrm{f}}$ (td, $J=7.4,1.3 \mathrm{~Hz}, 1 \mathrm{H}$, $\operatorname{ArH}), 7.43-7.52^{\mathrm{h}}(\mathrm{m}, 1 \mathrm{H}, \mathrm{ArH}), 7.63^{\mathrm{d}}(\mathrm{d}, J=8.0 \mathrm{~Hz}, \operatorname{ArH})$, $7.69^{\mathrm{e}}(\mathrm{dd}, J=7.6,1.1 \mathrm{~Hz}, 1 \mathrm{H}, \mathrm{ArH}), 7.81^{\mathrm{c}}(\mathrm{td}, J=7.8,1.5 \mathrm{~Hz}$, $1 \mathrm{H}, \mathrm{ArH})$ and $9.03^{\mathrm{a}}(\mathrm{d}, J=5.2 \mathrm{~Hz}, 1 \mathrm{H}, \mathrm{ArH}) ;{ }^{13} \mathrm{C} \mathrm{NMR}$ $\left(100 \mathrm{MHz} ; \mathrm{CDCl}_{3} ; \mathrm{Me}_{4} \mathrm{Si}\right)$ 28.36, 28.64, 41.07, 41.50, 93.22, $118.29,121.17,122.92,123.39,129.28,130.97,137.95,140.06$, 144.70, 147.11, 168.58, 193.76 and 195.12; $\mathrm{m} / \mathrm{z}$ (ESI): 533.2 $\left(\mathrm{M}^{+}-\mathrm{C}_{22} \mathrm{H}_{27} \mathrm{NO}_{2} \mathrm{Pt}\right.$ requires 532.17); $\lambda_{\text {max-absorption }}(n$-hexane) $/ \mathrm{nm}$ $251\left(\varepsilon / \mathrm{dm}^{3} \mathrm{~mol}^{-1} \mathrm{~cm}^{-1} 26100\right), 287$ (21 600), 326 (13 500), 335 (13 800), 363 (8700), 382 (9300), 408 (5100); $\lambda_{\text {max-emission }}{ }^{-}$ ( $n$-hexane)/nm 488, 524; Quantum yield( $n$-hexane)/\% 15.

\section{Complex 2. ${ }^{12}$}

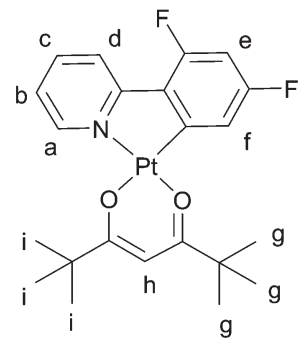

Dimer 2 (151 mg, $0.180 \mathrm{mmol}$ ), 2,2,6,6-tetramethyl-3,5-heptanedione (100 mg, $0.540 \mathrm{mmol}$ ) and $\mathrm{Na}_{2} \mathrm{CO}_{3}$ (191 mg, $1.800 \mathrm{mmol})$. After purification by column chromatography on silica gel $\left(\mathrm{CH}_{2} \mathrm{Cl}_{2}-n\right.$-hexane $1: 3$ as eluent) yellow crystals (74 mg, 36\%) (Found: C 47.08, H 4.23, N 2.49. $\mathrm{C}_{22} \mathrm{H}_{25} \mathrm{~F}_{2} \mathrm{NO}_{2} \mathrm{Pt}$ requires C 46.48, H 4.43, N 2.46); $v_{\max } / \mathrm{cm}^{-1} 2977,2948,2923$, 2901, 2858, 2362, 1605, 1545, 1530, 1497, 1437, 1397, 1362, 1297, 1243, 1225, 1189, 1160, 1143, 1114, 1095, 1066, 984, 956, 876, 848, 801, 768, 751, 737, 701, 658 and 633; ${ }^{1} \mathrm{H}$ NMR $\left(600 \mathrm{MHz} ; \mathrm{CDCl}_{3} ; \mathrm{Me}_{4} \mathrm{Si}\right) 1.31^{\mathrm{i}}\left(\mathrm{s}, 9 \mathrm{H}, \mathrm{CH}_{3}\right), 1.31^{\mathrm{g}}(\mathrm{s}, 9 \mathrm{H}$, $\left.\mathrm{CH}_{3}\right), 5.87^{\mathrm{h}}(\mathrm{s}, 1 \mathrm{H}, \mathrm{CH}), 6.60^{\mathrm{e}}(\mathrm{m}, 1 \mathrm{H}, \mathrm{ArH}), 7.15-7.19^{\mathrm{b}, \mathrm{f}}(\mathrm{m}$, $2 \mathrm{H}, \operatorname{ArH}), 7.86^{\mathrm{c}}(\mathrm{m}, J=1 \mathrm{H}, \mathrm{ArH}), 8.00^{\mathrm{d}}(\mathrm{d}, J=8.1 \mathrm{~Hz}, 1 \mathrm{H}$, $\mathrm{ArH}), 9.05^{\mathrm{a}}$ (d, $\left.J=6.1 \mathrm{~Hz}, 1 \mathrm{H}, \mathrm{ArH}\right) .{ }^{13} \mathrm{C} \mathrm{NMR}(100 \mathrm{MHz}$; $\left.\mathrm{CDCl}_{3} ; \mathrm{Me}_{4} \mathrm{Si}\right)$ 28.31, 28.37, 28.64, 28.86, 41.05, 41.46, 93.54, $99.19, \quad 112.90,121.12,122.05,138.59,147.06,194.25$, 195.49 ppm. ${ }^{19} \mathrm{~F}$ NMR (400 $\left.\mathrm{MHz}, \mathrm{CDCl}_{3}\right): \delta=-112.75$, -106.94 ppm; $m / z$ (ESI): $569.2\left(\mathrm{M}^{+}-\mathrm{C}_{22} \mathrm{H}_{25} \mathrm{~F}_{2} \mathrm{NO}_{2} \mathrm{Pt}\right.$ requires $568.15) ; \lambda_{\text {max-absorption }}(n$-hexane $) / \mathrm{nm} 250\left(\varepsilon / \mathrm{dm}^{3} \mathrm{~mol}^{-1} \mathrm{~cm}^{-1}\right.$ $29000), 282$ (22 400), 317 (15 000), 329 (16 500), 358 (9600), 374 (11000); $\lambda_{\text {max-emission }}(n$-hexane)/nm 468, 501; Quantum yield( $n$-hexane) $/ \% 9.1$.

\section{Complex 3.}

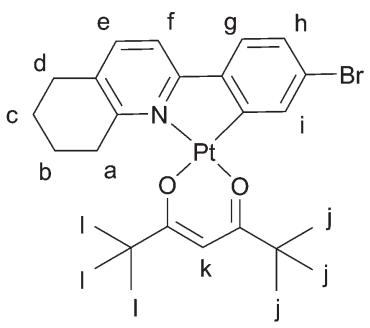

Dimer 3 (178 mg, $0.173 \mathrm{mmol}$ ), 2,2,6,6-tetramethyl-3,5-heptanedione (95 mg, $0.518 \mathrm{mmol})$ and $\mathrm{Na}_{2} \mathrm{CO}_{3}$ (183 mg, $1.725 \mathrm{mmol})$. After purification by column chromatography on silica gel $\left(\mathrm{CH}_{2} \mathrm{Cl}_{2}-n\right.$-hexane $1: 3$ as eluent) yellow crystals (150 mg, 65\%) (Found $\mathrm{C}$ 47.28, H 4.99, N 2.16. $\mathrm{C}_{26} \mathrm{H}_{32} \mathrm{BrNO}_{2} \mathrm{Pt}$ requires $\left.\mathrm{C} 46.92, \mathrm{H} 4.85, \mathrm{~N} 2.10\right) ; v_{\max } / \mathrm{cm}^{-1}$ 2955, 2934, 2905, 2866, 2366, 2334, 1591, 1587, 1548, 1526, $1497,1443,1412,1389,1358,1243,1221,1185,1143,1070$, 1038, 873, 822, 794, 751, 708, 654 and 614; ${ }^{1} \mathrm{H}$ NMR (600 MHz; $\left.\mathrm{CDCl}_{3} ; \mathrm{Me}_{4} \mathrm{Si}\right) 1.24^{1}\left(\mathrm{~s}, 9 \mathrm{H}, \mathrm{CH}_{3}\right), 1.31^{\mathrm{j}}(\mathrm{s}, 9 \mathrm{H}$, $\left.\mathrm{CH}_{3}\right), 1.79-1.92^{\mathrm{b}, \mathrm{c}}\left(\mathrm{m}, 4 \mathrm{H}, \mathrm{CH}_{2}\right), 2.82^{\mathrm{d}}(\mathrm{t}, J=6.3 \mathrm{~Hz}, 2 \mathrm{H}$, $\left.\mathrm{CH}_{2}\right), 3.57^{\mathrm{a}}\left(\mathrm{t}, J=6.4 \mathrm{~Hz}, 2 \mathrm{H}, \mathrm{CH}_{2}\right), 5.88^{\mathrm{k}}(\mathrm{s}, 1 \mathrm{H}, \mathrm{CH})$, $7.19-7.24^{\mathrm{g}, \mathrm{h}}(\mathrm{m}, 2 \mathrm{H}, \mathrm{ArH}), 7.37^{\mathrm{f}}(\mathrm{d}, J=8.1 \mathrm{~Hz}, 1 \mathrm{H}, \mathrm{ArH}), 7.46^{\mathrm{e}}$ (d, $J=8.1 \mathrm{~Hz}, 1 \mathrm{H}, \mathrm{ArH}), 7.86^{\mathrm{i}}(\mathrm{d}, J=1.7 \mathrm{~Hz}, 1 \mathrm{H}, \mathrm{ArH}) \mathrm{ppm}$. ${ }^{13} \mathrm{C}$ NMR (100 MHz; $\left.\mathrm{CDCl}_{3} ; \mathrm{Me}_{4} \mathrm{Si}\right)$ 21.81, 22.91, 28.51, 28.69, 29.10, 30.89, 32.25, 40.69, 42.21, 92.51, 115.31, 121.97, $123.66,126.43,131.55,132.36,138.24,138.98,145.15,162.74$, 165.77, 193.56, 195.48, $206.79 \mathrm{ppm} ; \mathrm{m} / z$ (ESI): 666.1 $\left(\mathrm{M}^{+}-\mathrm{C}_{26} \mathrm{H}_{32} \mathrm{BrNO}_{2} \mathrm{Pt}\right.$ requires 664.13$) ; \lambda_{\text {max-absorption }}(n$-hexane)/ $\mathrm{nm} 254\left(\varepsilon / \mathrm{dm}^{3} \mathrm{~mol}^{-1} \mathrm{~cm}^{-1} 18900\right), 286$ (21 500), 324 (3900), 340 (8400), $380 \quad$ (5600); $\lambda_{\text {max-emission }}(n$-hexane)/nm 505, 535; Quantum yield( $n$-hexane)/\% 10.8 .

\section{Complex 4.}

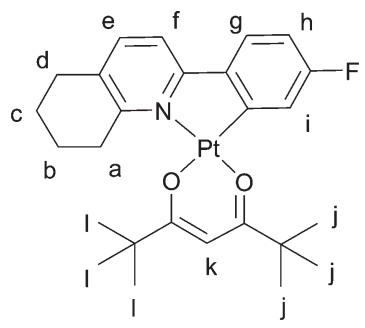

Dimer 4 (105 mg, $0.115 \mathrm{mmol}$ ), 2,2,6,6-tetramethyl-3,5-heptanedione (71 mg, $0.385 \mathrm{mmol})$ and $\mathrm{Na}_{2} \mathrm{CO}_{3}$ (136 mg, $1.280 \mathrm{mmol})$. After purification by column chromatography on silica gel $\left(\mathrm{CH}_{2} \mathrm{Cl}_{2}-n\right.$-hexane $1: 3$ as eluent) yellow crystals (110 mg, 79\%) (Found C 51.70, H 5.46, N 1.71. $\mathrm{C}_{26} \mathrm{H}_{32} \mathrm{FNO}_{2} \mathrm{Pt}$ requires C 51.65, H 5.33, N 2.32); $v_{\max } / \mathrm{cm}^{-1} 2995,2934,2858$, $1587,1545,1530,1494,1451,1412,1389$, 1358, 1308, 1268, $1243,1221,1185,1142,873,848$ and $791 ;{ }^{1} \mathrm{H}$ NMR $(600 \mathrm{MHz}$; $\left.\mathrm{CDCl}_{3} ; \mathrm{Me}_{4} \mathrm{Si}\right) 1.23^{\mathrm{l}}\left(\mathrm{s}, 9 \mathrm{H}, \mathrm{CH}_{3}\right), 1.30^{\mathrm{j}}\left(\mathrm{s}, 9 \mathrm{H}, \mathrm{CH}_{3}\right)$, $1.77-1.94^{\mathrm{b}, \mathrm{c}}\left(\mathrm{m}, 4 \mathrm{H}, \mathrm{CH}_{2}\right), 2.81^{\mathrm{d}}\left(\mathrm{t}, J=6.2 \mathrm{~Hz}, 2 \mathrm{H}, \mathrm{CH}_{2}\right), 3.56^{\mathrm{a}}$ $\left(\mathrm{t}, J=6.2 \mathrm{~Hz}, 2 \mathrm{H}, \mathrm{CH}_{2}\right), 5.88^{\mathrm{k}}(\mathrm{s}, 1 \mathrm{H}, \mathrm{CH}), 6.79^{\mathrm{h}}(\mathrm{td}, J=8.6$, $2.6 \mathrm{~Hz}, 1 \mathrm{H}, \mathrm{ArH}), 7.30-7.40^{\mathrm{f}, \mathrm{g}, \mathrm{i}}(\mathrm{m}, 3 \mathrm{H}, \mathrm{ArH}), 7.44^{\mathrm{e}}(\mathrm{d}, J=$ $8.1 \mathrm{~Hz}, 1 \mathrm{H}, \mathrm{ArH}) \mathrm{ppm} .{ }^{13} \mathrm{C} \mathrm{NMR}\left(100 \mathrm{MHz} ; \mathrm{CDCl}_{3} ; \mathrm{Me}_{4} \mathrm{Si}\right)$ $21.85,22.94,28.50,28.71,29.03,32.24,40.78,42.70,92.52$, $110.49,110.72,115.05,115.79,115.98,123.97,124.06,130.85$, $139.01,142.47,162.44,165.84,193.48,195.49$ ppm. ${ }^{19} \mathrm{~F}$ NMR 
(400 $\mathrm{MHz}, \mathrm{CDCl}_{3}$ ): $\delta=-75.21 \mathrm{ppm} ; \mathrm{m} / \mathrm{z}$ (ESI): 605.2 $\left(\mathrm{M}^{+}-\mathrm{C}_{26} \mathrm{H}_{32} \mathrm{FNO}_{2} \mathrm{Pt}\right.$ requires 604.21); $\lambda_{\text {max-absorption }}(n$-hexane $) /$ $\mathrm{nm} 251\left(\varepsilon / \mathrm{dm}^{3} \mathrm{~mol}^{-1} \mathrm{~cm}^{-1} 17500\right), 280$ (17900), 318 (6400), 336 (5500), 374 (5300), 391 (3500); $\lambda_{\text {max-emission }}(n$-hexane) $/ \mathrm{nm}$ 491, 526; Quantum yield( $n$-hexane) $/ \% 5.2$.

\section{Complex 5.}

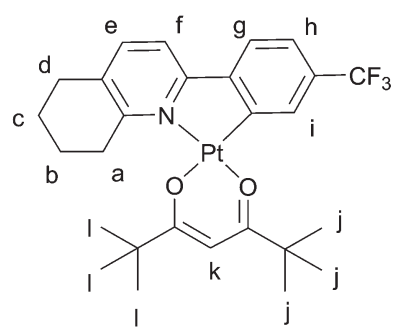

Dimer 5 (103 mg, $0.099 \mathrm{mmol}$ ), 2,2,6,6-tetramethyl-3,5-heptanedione $(55 \mathrm{mg}, 0.296 \mathrm{mmol})$ and $\mathrm{Na}_{2} \mathrm{CO}_{3}(105 \mathrm{mg}$, $0.990 \mathrm{mmol}$ ). After purification by column chromatography on silica gel $\left(\mathrm{CH}_{2} \mathrm{Cl}_{2}-n\right.$-hexane 1:3 as eluent) yellow solid $(66 \mathrm{mg}$, 50\%) (Found C 49.57, H 4.31, N 2.29. $\mathrm{C}_{27} \mathrm{H}_{32} \mathrm{~F}_{3} \mathrm{NO}_{2} \mathrm{Pt}$ requires C 49.54, H 4.93, N 2.14); $v_{\max } / \mathrm{cm}^{-1} 2966,2930,2866,2362$, $1591,1562,1530,1497,1480,1454,1412,1389,1362,1311$, $1243,1164,1120,1074,959,902,873,808,791,747,712,650$ and 610; ${ }^{1} \mathrm{H}$ NMR $\left(600 \mathrm{MHz} ; \mathrm{CDCl}_{3} ; \mathrm{Me}_{4} \mathrm{Si}\right) 1.25^{1}$ (s, 9H, $\left.\mathrm{CH}_{3}\right), \quad 1.31^{\mathrm{j}}\left(\mathrm{s}, 9 \mathrm{H}, \mathrm{CH}_{3}\right), \quad 1.79-1.94^{\mathrm{b}, \mathrm{c}}\left(\mathrm{m}, 4 \mathrm{H}, \mathrm{CH}_{2}\right)$, $2.81-2.83^{\mathrm{d}}\left(\mathrm{t}, J=6.3 \mathrm{~Hz}, 2 \mathrm{H}, \mathrm{CH}_{2}\right), 3.56-3.63^{\mathrm{a}}(\mathrm{t}, J=6.4 \mathrm{~Hz}$, $\left.2 \mathrm{H}, \mathrm{CH}_{2}\right), 5.90^{\mathrm{k}}(\mathrm{s}, 1 \mathrm{H}, \mathrm{CH}), 7.32^{\mathrm{h}}(\mathrm{dd}, J=8.0,1.3 \mathrm{~Hz}, 1 \mathrm{H}$, $\operatorname{ArH}), 7.43^{\mathrm{g}}(\mathrm{d}, J=8.1 \mathrm{~Hz}, 1 \mathrm{H}, \operatorname{ArH}), 7.46^{\mathrm{f}}(\mathrm{d}, J=8.1 \mathrm{~Hz}, 1 \mathrm{H}$, ArH), $7.50^{\mathrm{e}}(\mathrm{d}, J=8.1 \mathrm{~Hz}, 1 \mathrm{H}, \mathrm{ArH}), 8.05^{\mathrm{i}}(\mathrm{d}, J=1.3 \mathrm{~Hz}, 1 \mathrm{H}$, ArH) ppm. ${ }^{13} \mathrm{C}$ NMR $\left(100 \mathrm{MHz} ; \mathrm{CDCl}_{3} ; \mathrm{Me}_{4} \mathrm{Si}\right) 21.75,22.87$, $28.51,28.62,29.15,32.33,40.81,42.24,53.39,92.58,115.84$, $120.26,122.03,126.25,132.50,136.20,139.04,149.56,163.10$, 165.20, 193.71, 195.63 ppm. ${ }^{19} \mathrm{~F}$ NMR $\left(400 \mathrm{MHz}, \mathrm{CDCl}_{3}\right): \delta=$ $-63.21 \mathrm{ppm} ; \mathrm{m} / \mathrm{z}$ (ESI): $655.2\left(\mathrm{M}^{+}-\mathrm{C}_{27} \mathrm{H}_{32} \mathrm{~F}_{3} \mathrm{NO}_{2} \mathrm{Pt}\right.$ requires $654.20) ; \lambda_{\text {max-absorption }}\left(n\right.$-hexane) $/ \mathrm{nm} 252\left(\varepsilon / \mathrm{dm}^{3} \mathrm{~mol}^{-1} \mathrm{~cm}^{-1}\right.$ 19300), 285 (18600), 307 (5100), 337 (6100), 392 (6000), 410 (4400); $\lambda_{\text {max-emission }}(n$-hexane) $/ \mathrm{nm}$ 501，538; Quantum $\operatorname{yield}(n$-hexane) $/ \% 6.9$.

\section{Acknowledgements}

The authors acknowledge the DFG (Deutsche Forschungsgemeinschaft) for financially supporting this work with grant applications HO3911/3-1 and HO3911/6-1. E. H. acknowledges Prof. Ullrich Scherf for granting access to the tools of the Macromolecular Chemistry at the University of Wuppertal (BUW) and Melanie Dausend and Ilka Polanz (Organic Chemistry, BUW) for performing routine mass spectrometry as well as Ralf Radon (Analytical Chemistry, BUW) and the group of Prof. Klaus Meerholz at the University of Cologne for their help with the elemental analysis.

\section{Notes and references}

1 M. A. Baldo, D. F. O’Brien, Y. You, A. Shoustikov, S. Sibley, M. E. Thompson and S. R. Forrest, Nature, 1998, 395, 151; E. Holder, B. M. W. Langeveld and U. S. Schubert, Adv. Mater., 2005, 17, 1109; N. Rehmann, C. Ulbricht, A. Köhnen, P. Zacharias, M. C. Gather,
D. Hertel, E. Holder, K. Meerholz and U. S. Schubert, Adv. Mater, 2008, 20, 129; N. Tian, A. Thiessen, R. Schiewek, O. J. Schmitz, D. Hertel, K. Meerholz and E. Holder, J. Org. Chem., 2009, 74, 2718; C. Ulbricht, N. Rehmann, E. Holder, D. Hertel, K. Meerholz and U. S. Schubert, Macromol. Chem. Phys., 2009, 210, 531; N. Tian, Y. V. Aulin, D. Lenkeit, S. Pelz, O. V. Mikhnenko, P. W. M. Blom, M. A. Loi and E. Holder, Dalton Trans., 2010, 39, 8613; N. Tian, D. Lenkeit, S. Pelz, D. Kourkoulos, D. Hertel, K. Meerholz and E. Holder, Dalton Trans., 2011, 40, 11629.

2 B. O'Regan and M. Grätzel, Nature, 1991, 353, 737; V. Marin, E. Holder, M. M. Wienk, E. Tekin, D. Kozodaev and U. S. Schubert, Macromol. Rapid Commun., 2005, 26, 319; V. Marin, E. Holder and U. S. Schubert, J. Polym. Sci., Part A: Polym. Chem., 2004, 42, 374.

3 C. Li, J. Lin and Y. S. Guo Zhang, Chem. Commun., 2011, 47, 4442; E. Holder, M. A. R. Meier, V. Marin and U. S. Schubert, J. Polym. Sci., Part A: Polym. Chem., 2003, 41, 3954; V. Marin, E. Holder, M. A. R. Meier, R. Hoogenboom and U. S. Schubert, Macromol. Rapid Commun., 2004, 25, 793; E. Holder, D. Oelkrug, H.-J. Egelhaaf, H. A. Mayer and E. Lindner, J. Fluoresc., 2002, 12, 383.

4 I. Gryczynski, J. Malicka, E. Holder, N. DiCesare and J. R. Lakowicz, Chem. Phys. Lett., 2003, 372, 409; E. Holder, G. Schoetz, V. Schurig and E. Lindner, Tetrahedron: Asymmetry, 2001, 12, 2289; E. Holder, G. Trapp, J. C. Grimm, V. Schurig and E. Lindner, Tetrahedron: Asymmetry, 2002, 13, 2673; E. Holder, O. Trapp, G. Trapp, V. Marin, R. Hoogenboom and U. S. Schubert, Chirality, 2004, 16, 363.

5 L. H. Fischer, M. I. J. Stich, O. S. Wolfbeis, N. Tian, E. Holder and M. Schäferling, Chem.-Eur. J., 2009, 15, 10857.

6 N. Tian, D. Lenkeit, S. Pelz, L. H. Fischer, D. Escudero, R. Schiewek, D. Klink, O. J. Schmitz, L. González, M. Schäferling and E. Holder, Eur. J. Inorg. Chem., 2010, 4875.

7 J. A. G. Williams, A. J. Wilkinson and V. L. Whittle, Dalton Trans., 2008, 2081; H. J. Bolink, E. Coronado, S. G. Santamaria, M. Sessolo, N. Evans, C. Klein, E. Baranoff, K. Kalyanasundaram, M. Graetzel and M. K. Nazeeruddin, Chem. Commun., 2007, 3276; E. Holder, V. Marin, D. Kozodaev, M. A. R. Meier, B. G. G. Lohmeijer and U. S. Schubert, Macromol. Chem. Phys., 2005, 206, 989; V. Marin, E. Holder, R. Hoogenboom, E. Tekin and U. S. Schubert, Dalton Trans., 2006, 1636; V. Marin, E. Holder, R. Hoogenboom and U. S. Schubert, Chem. Soc. Rev., 2007, 36, 618; E. Tekin, E. Holder, V. Marin, B.-J. de Gans and U. S. Schubert, Macromol. Rapid Commun., 2005, 26, 293; V. Marin, E. Holder, R. Hoogenboom and U. S. Schubert, J. Polym. Sci., Part A: Polym. Chem., 2004, 42, 4153; E. Holder, V. Marin, M. A. R. Meier and U. S. Schubert, Macromol. Rapid Commun., 2004, 25, 1491.

8 M. Schäferling, Luminescence lifetime-based imaging of sensor arrays for high-throughput screening applications, in Springer Series on Chemical Sensors and Biosensors Vol. 3, ed. G. Orellana and M. C. MorenoBondi, Springer, Berlin, 2005.

9 B. Zelelow, G. E. Khalil, G. Phelan, B. Carlson, M. Gouterman, J. B. Callis and L. R. Dalton, Sens. Actuators, B, 2003, 96, 304.

10 C. Kuhnt, M. Karnahl, S. Tschierlei, K. Griebenow, M. Schmitt, B. Schäfer, S. Krieck, H. Görls, S. Rau, B. Dietzek and J. Popp, Phys. Chem. Chem. Phys., 2010, 12, 1357; J. V. Houten and R. J. Watts, J. Am. Chem. Soc., 1976, 98, 4853; S. H. Fan, K. Z. Wang and W. C. Yang, Eur. J. Inorg. Chem., 2009, 508.

11 Z. He, W.-Y. Wong, X. Yu, H.-S. Kwok and Z. Lin, Inorg. Chem., 2006, 45, 10922-10937.

12 J. Brooks, Y. Babayan, S. Lamansky, P. I. Djurovich, I. Tsyba, R. Bau and M. E. Thompson, Inorg. Chem., 2002, 41, 3055.

13 K. M.-C. Wong, W.-S. Tang, X.-X. Lu, N. Zhu and V. W.-W. Yam, Inorg. Chem., 2005, 44, 1492.

14 J. Kalinowski, V. Fattori, M. Cocchi and J. A. G. Williams, Coord. Chem. Rev., 2011, 255, 2401; C.-C. Kwok, H. M. Y. Ngai, S.-C. Chan, I. H. T. Sham, C.-M. Che and N. Zhu, Inorg. Chem., 2005, 44, 4442.

15 J. E. McGarrah, Y.-J. Kim, M. Hissler and R. Eisenberg, Inorg. Chem., 2001, 40, 4510 .

16 A. Islam, H. Sugihara, K. Hara, L. P. Singh, R. Katoh, M. Yanagida, Y. Takahashi, S. Murata and H. Arakawa, Inorg. Chem., 2001, 40, 5371.

17 R. C. Evans, P. Douglas, J. A. G. Williams and D. L. Rocheste, J. Fluoresc., 2006, 16, 201.

18 X. Mou, Y. Wu, S. Liu, M. Shi, X. Liu, C. Wang, S. Sun, Q. Zhao, X. Zhou and W. Huang, J. Mater. Chem., 2011, 21, 13951.

19 G. E. Khalil, C. Costin, J. Crafton, G. Jones, S. Grenoble, M. Gouterman, J. B. Callis and L. R. Dalton, Sens. Actuators, B, 2004, 97, 13. 
20 S. M. Borisov, A. S. Vasylevska, C. Krause and O. S. Wolfbeis, Adv. Funct. Mater, 2006, 16, 1536.

21 H. Sun, H. Guo, W. Wu, X. Liu and J. Zhao, Dalton Trans., 2011, 40, 7834.

22 S. M. Borisov, G. Zenkl and I. Klimant, ACS Appl. Mater. Interfaces, 2010, 2, 366.

23 M. E. Köse, B. F. Carroll and K. S. Schanze, Langmuir, 2005, 21, 9121.

24 A. Tsami, X.-H. Yang, T. Farrell, D. Neher and E. Holder, J. Polym. Sci., Part A: Polym. Chem., 2008, 46, 7794; A. Tsami, X.-H. Yang, F. Galbrecht, T. Farrell, H. Li, S. Adamczyk, R. Heiderhoff, L. J. Balk, D. Neher and E. Holder, J. Polym. Sci., Part A: Polym. Chem., 2007, 45, 4773; I. Kanelidis, Y. Ren, V. Lesnyak, J. C. Gasse, R. Frahm, A. Eychmüller and E. Holder, J. Polym. Sci., Part A: Polym. Chem., 2011, 49, 392; I. Kanelidis, O. Altintas, J.-C. Gasse, R. Frahm, A. Eychmüller and E. Holder, Polym. Chem., 2011, 2, 2597.

25 J. Hummel, Untersuchungen zur effizienten Synthese verbrückter und funktionalisierter U- und S-förmiger Terpyridine, Dissertation, Universität-GH Paderborn, 2007.

26 E. C. Constable and P. Harverson, Inorg. Chim. Acta, 1996, 252, 9.

27 D. Sielemann, Synthese polycyclischer Pyridinderivate - Mannich-Basen und Iminiumsalze als Schlüsselbausteine für den Aufbau neuartiger Ligandsysteme, Dissertation, Universität-GH Paderborn, 2000.

28 A. Winter, C. Ulbricht, E. Holder, N. Risch and U. S. Schubert, Aust. J. Chem., 2006, 59, 773.

29 B. N. Cockburn, D. V. Howe, T. Keating, B. F. G. Johnson and J. Lewis, J. Chem. Soc., Dalton Trans., 1973, 404.

30 L. Chassot, E. Müller and A. von Zelewsky, Inorg. Chem., 1984, 23, 4249.

31 M. Maestri, D. Sandrini, V. Balzani, L. Chasson, P. Jolliet and A. von Zelewsky, Chem. Phys. Lett., 1985, 122, 375.

32 L. Chassot and A. von Zelewsky, Inorg. Chem., 1987, 26, 2814.

33 P. Jolliet, M. Gianini, A. von Zelewsky, G. Bernardinelli and H. StoeckliEvans, Inorg. Chem., 1996, 35, 4883.

34 J.-C. Shi, H.-Y. Chao, W.-F. Fu, S.-M. Peng and C.-M. Che, J. Chem. Soc., Dalton Trans., 2000, 3128.
35 K. P. Balashev, T. Engebretsen, P. I. Kvam, K. Maartmann-Moe, M. V. Puzyk and J. Songstad, Acta Chem. Scand., 1996, 50, 1108.

36 C. Moore, S. P. Chan, J. N. Demas and B. A. DeGraff, Appl. Spectrosc., 2004, 58, 603.

37 M. I. Stich and O. S. Wolfbeis, Fluorescence Sensing and Imaging Using Pressure-Sensitive Paints and Temperature-Sensitive Paints, Springer, 2008.

38 S. Draxler, M. E. Lippitsch, I. Klimant, H. Kraus and O. S. Wolfbeis, J. Phys. Chem., 1995, 99, 3162.

39 M. Schäferling, Angew. Chem., Int. Ed., 2012, 51, 3532.

40 G. Liebsch, I. Klimant, B. Frank, G. Holst and O. S. Wolfbeis, Appl. Spectrosc., 2000, 54, 548.

41 J. H. Bell, E. T. Schairer, L. A. Hand and R. D. Mehta, Annu. Rev. Fluid Mech., 2001, 33, 155.

42 Y. Amaoa, Y. Ishikawa and I. Okura, Anal. Chim. Acta, 2001, 445, 177.

43 J. N. Demas and B. A. DeGraff, Anal. Chem., 1991, 63, 829A.

44 S.-K. Lee and I. Okura, Anal. Commun., 1997, 34, 185.

45 I. M. P. de Vargas-Sansalvador, A. Martinez-Olmos, A. J. Palma, M. D. Fernández-Ramos and L. F. Capitán-Vallvey, Microchim. Acta, 2010, 172, 455.

46 E. R. Carraway, J. N. Demas, B. A. DeGraff and J. R. Bacon, Anal. Chem., 1991, 63, 337.

47 G. Liebsch, I. Klimant and O. S. Wolfbeis, Adv. Mater., 1999, 11, 1296; M. E. Köse, B. F. Caroll and K. S. Schanze, Langmuir, 2005, 21, 921929.

48 M. I. J. Stich, S. Nagl, O. S. Wolfbeis, U. Henne and M. Schäferling, Adv. Funct. Mater., 2008, 18, 1399; S. M. Borisov and O. S. Wolfbeis, Anal. Chem., 2006, 78, 5094.

49 R. Carlson, Å. Nilsson and M. Strömqvist, Acta Chem. Scand., Ser. B, 1983, 37b, 7 .

50 M. Gaudry, Y. Jasor and T. B. Khac, Org. Synth., 1979, 59, 153.

51 L. F. Tietze and T. Eicher, Reaktionen und Synthesen im organischchemischen Praktikum, 1. Aufl., Thieme-Verlag, Stuttgart, 1981.

52 A. F. Casy and J. L. Myers, J. Chem. Soc., 1965, 4092. 